\title{
PERAN USAHA MIKRO DAN KECIL DALAM PENGENTASAN KEMISKINAN DI DAERAH
}

\section{THE ROLE OF MICRO AND SMALL ENTERPRISE IN REGIONAL POVERTY ALLEVATION}

\author{
Tulus T.H.Tambunan \\ Center for Industry, SME and Business Competition Studies \\ Universitas Trisakti, Gedung S Lantai 5 No. 22, Kampus A, \\ Jl. Kyai Tapa No.1, Grogol Jakarta 11440 Indonesia; e-mail: sjahrir@rad.net.id \\ Diterima: 15 Mei 2012, Direvisi: 27 Mei 2012, Disetujui: 31 Mei 2012
}

\begin{abstract}
Abstrak
Tujuan utama dari studi ini adalah mengeksplorasi peran usaha mikro dan kecil (UMK) dalam pengentasan kemiskinan di daerah. Lebih spesifik lagi, studi ini bermaksud menjawab dua pertanyaan penelitian berikut ini. Pertama, apakah keberadaan UMK bisa mengurangi kemiskinan di daerah? Kedua, apakah derajat pentingnya UMK bagi pengentasan kemiskinan bervariasi menurut daerah dan apa kemungkinan faktor-faktor penentunya? Penelitian ini didasarkan pada analisa data sekunder dengan memakai data kemiskinan dan UMK di industri manufaktur pada tingkat provinsi. Pentingnya keberadaan UMK diukur secara tidak langsung dengan lima indikator: jumlah unit usaha, jumlah pekerja yang dibayar, produktivitas, pangsa output, dan nilai ekspor. Hasil penelitian ini memberi kesan bahwa UMK memang penting bagi pengurangan kemiskinan di daerah (provinsi). Namun, perannya itu bervariasi menurut provinsi yang ditentukan oleh perbedaan-perbedaan dalam akses UMK ke inputinput penting seperti pendidikan, bantuan teknis, bahan baku dan permodalan.

Kata Kunci: UMK, kemiskinan, produktivitas, pangsa output.
\end{abstract}

\begin{abstract}
The main objective of this study is to explore the role of micro and small enterprises (MSEs) in regional poverty alleviation. More specific, this study aims to answer the following two research questions. First, can the presence of MSEs reduce regional poverty? Second, does the degree of the importance of MSEs for poverty reduction vary by region and what are the likely determinants?This research is based on secondary data analysis by using data on poverty and MSEs in the manufacturing industry at the provincial level. The importance of MSEs is measured indirectly with five indicators: total units, total paid workers, productivity, output share, value of export. Finding of this research suggests that MSEs are indeed for poverty regional reduction (province). However, their role varies by province which is determined by differences in MSEs' access to crucial inputs such as education, technical assistance, raw materials and capital.
\end{abstract}

Keywords: MSE, poverty, productivity, output share.

\section{PENDAHULUAN}

Seperti di belahan dunia lainnya, usaha mikro dan kecil (UMK) juga memainkan peran yang sangat penting di dalam perekonomian di kawasan Asia, terutama sebagai sumber utama kesempatan kerja dan salah satu sumber penting pertumbuhan ekonomi. Dengan besar sumbangan terhadap penciptaan kesempatan kerja, dengan sendirinya kelompok usaha tersebut juga dianggap sangat penting terhadap pengurangan kemiskinan. Perannya ini terkait dengan sejumlah karakteristik utama dari kelompok usaha tersebut, yakni antara lain: (1) Jumlahnya sangat banyak, dan berbeda dengan usaha menengah dan besar (UMB), UMK tersebar di seluruh pelosok perdesaan, termasuk di wilayah-wilayah yang relatif terisolasi; (2) Sangat padat karya, khususnya dari golongan angkatan kerja berpendidikan rendah, dan wanita; dan (3) Banyak kegiatan UMK yang berbasis pertanian, seperti industri-industri rumah tangga yang membuat makanan dan minuman, dan meubel serta berbagai macam produk kerajinan berbasis bahan baku bambu, kayu dan rotan, dan di Indonesia, sebagian besar penduduk miskin tinggal di perdesaan dan bersumber pendapatan dari sektor pertanian. Selain itu, UMK pada umumnya memproduksi barang-barang konsumsi termasuk makanan dan minuman, pakaian jadi, alas kaki, dan perabotan rumah tangga dengan harga murah untuk kalangan masyarakat berpendapatan rendah, sehingga keberadaan mereka sangat membantu rumah tangga-rumah tangga miskin.

Namun demikian, banyak bukti yang menunjukkan bahwa besarnya sumbangan UMK terhadap pembentukan Produk Domestik Bruto (PDB) bukan karena kelompok usaha tersebut sangat efisien atau produktif, melainkan karena jumlahnya memang sangat banyak, yang rata-rata mencapai 
sekitar 99\% dari jumlah unit usaha yang ada. Bahkan UMK sering dianggap sebagai kelompok usaha yang tidak efisien, tidak kompetitif dan oleh karena itu sangat sulit berkembang menjadi usaha-usaha yang modern atau menjadi UMB. Di Indonesia, sejak awal periode Orde Baru (1966-1998) hingga sekarang ini sudah banyak upaya yang dilakukan pemerintah untuk mendukung UMK dengan berbagai program dan kebijakan/peraturan, termasuk menerbitkan Undang-Undang (UU) UMKM No.20 Tahun 2008. Program-program yang telah/masih dilakukan mulai dari berbagai skim kredit bersubsidi mulai dari KIK (Kredit Investasi Kecil) dan KMKP (Kredit Modal Kerja Permanen) pada dekade 1970-an hingga KUR (Kredit Usaha Rakyat) yang diperkenalkan oleh
Presiden SBY. Namun fakta menunjukkan bahwa kinerja UMK di Indonesia masih relatif buruk bukan saja dibandingkan dengan UMB, tetapi juga dibandingkan dengan UMK di negara-negara maju. Berdasarkan hasil observasinya terhadap usaha mikro (UMI), usaha kecil (UK), dan usaha menengah (UM) di Indonesia dan penelitian literatur mengenai kelompok-kelompok usaha tersebut di banyak negara berkembang lainnya, Tambunan (2009a) menyimpulkan bahwa kendala-kendala yang dihadapi oleh UMK dan prospek perkembangannya ke depan sangat erat kaitannya atau sangat dipengaruhi oleh karakteristik-karakteristiknya seperti yang dijabarkan di Tabel 1.

Tabel 1. Karakteristik-Karakteristik Utama dari UMI, UK, dan UM di Indonesia

\begin{tabular}{|c|c|c|c|c|}
\hline No & Aspek & UMI & UK & UM \\
\hline 1 & Formalitas & $\begin{array}{l}\text { Beroperasi di sektor } \\
\text { informal; usaha tidak } \\
\text { terdaftar; tidak/jarang bayar } \\
\text { pajak }\end{array}$ & $\begin{array}{l}\text { Beberapa beroperasi di } \\
\text { sektor formal; beberapa } \\
\text { tidak terdaftar; sedikit yang } \\
\text { bayar pajak }\end{array}$ & $\begin{array}{l}\text { Semua di sektor formal; } \\
\text { terdaftar dan bayar pajak }\end{array}$ \\
\hline 2 & $\begin{array}{l}\text { Organisasi \& } \\
\text { manajemen }\end{array}$ & $\begin{array}{l}\text { Dijalankan oleh pemilik; } \\
\text { tidak menerapkan } \\
\text { pembagian tenaga kerja } \\
\text { internal (ILD), manajemen } \\
\text { \& struktur organisasi formal } \\
\text { (MOF), sistem pembukuan } \\
\text { formal (ACS) }\end{array}$ & $\begin{array}{l}\text { Dijalankan oleh pemilik; } \\
\text { tidak ada ILD, MOF, ACS }\end{array}$ & $\begin{array}{l}\text { Banyak yang mengerjakan } \\
\text { manajer profesional dan } \\
\text { menerapkan ILD, MOF, } \\
\text { ACS }\end{array}$ \\
\hline 3 & $\begin{array}{l}\text { Sifat dari } \\
\text { kesempatan } \\
\text { kerja }\end{array}$ & $\begin{array}{l}\text { Kebanyakan menggunakan } \\
\text { anggota-anggota keluarga } \\
\text { tidak dibayar }\end{array}$ & $\begin{array}{l}\text { Beberapa memakai tenaga } \\
\text { kerja (TK) yang digaji }\end{array}$ & $\begin{array}{l}\text { - Semua memakai TK digaji } \\
\text { - Semua memiliki sistem } \\
\text { perekrutan formal }\end{array}$ \\
\hline 4 & $\begin{array}{l}\text { Pola/sifat dari } \\
\text { proses produksi }\end{array}$ & $\begin{array}{l}\text { derajat mekanisasi sangat } \\
\text { rendah/umumnya manual; } \\
\text { tingkat teknologi sangat } \\
\text { rendah }\end{array}$ & $\begin{array}{l}\text { beberapa memakai mesin- } \\
\text { mesin terbaru }\end{array}$ & $\begin{array}{l}\text { banyak yang punya derajat } \\
\text { mekanisasi yang } \\
\text { tinggi/punya akses terhadap } \\
\text { teknologi tinggi }\end{array}$ \\
\hline 5 & Orientasi pasar & $\begin{array}{l}\text { umumnya menjual ke pasar } \\
\text { lokal untuk kelompok } \\
\text { berpendapatan rendah }\end{array}$ & $\begin{array}{l}\text { banyak yang menjual ke } \\
\text { pasar domestik dan ekspor, } \\
\text { dan melayani kelas } \\
\text { menengah ke atas }\end{array}$ & $\begin{array}{l}\text { semua menjual ke pasar } \\
\text { domestik dan banyak yang } \\
\text { ekspor, dan melayani kelas } \\
\text { menengah ke atas }\end{array}$ \\
\hline 6 & $\begin{array}{l}\text { Profil ekonomi } \\
\& \text { sosial dari } \\
\text { pemilik usaha }\end{array}$ & $\begin{array}{l}\text { pendidikan rendah \& dari } \\
\text { rumah tangga (RT) miskin; } \\
\text { motivasi utama: survival }\end{array}$ & $\begin{array}{l}\text { banyak berpendidikan baik } \\
\& \text { dari RT non-miskin; } \\
\text { banyak yang bermotivasi } \\
\text { bisnis/ mencari profit }\end{array}$ & $\begin{array}{l}\text { sebagian besar } \\
\text { berpendidikan baik dan dari } \\
\text { RT makmur; motivasi } \\
\text { utama: profit }\end{array}$ \\
\hline 7 & $\begin{array}{l}\text { Sumber-sumber } \\
\text { dari bahan baku } \\
\text { dan modal }\end{array}$ & $\begin{array}{l}\text { kebanyakan pakai bahan } \\
\text { baku lokal dan uang sendiri }\end{array}$ & $\begin{array}{l}\text { beberapa memakai bahan } \\
\text { baku impor dan punya akses } \\
\text { ke kredit formal }\end{array}$ & $\begin{array}{l}\text { banyak yang memakai bahan } \\
\text { baku impor dan punya akses } \\
\text { ke kredit formal }\end{array}$ \\
\hline 8 & $\begin{array}{l}\text { Hubungan- } \\
\text { hubungan } \\
\text { eksternal }\end{array}$ & $\begin{array}{l}\text { kebanyakan tidak punya } \\
\text { akses ke program-program } \\
\text { pemerintah dan tidak punya } \\
\text { hubungan-hubungan bisnis } \\
\text { dengan UB }\end{array}$ & $\begin{array}{l}\text { banyak yang punya akses ke } \\
\text { program-program } \\
\text { pemerintah dan punya } \\
\text { hubungan-hubungan bisnis } \\
\text { dengan UB (termasuk } \\
\text { penanaman modal } \\
\text { asing/PMA). }\end{array}$ & $\begin{array}{l}\text { sebagian besar punya akses } \\
\text { ke program-program } \\
\text { pemerintah dan banyak yang } \\
\text { punya hubungan-hubungan } \\
\text { bisnis dengan UB (termasuk } \\
\text { PMA). }\end{array}$ \\
\hline 9 & $\begin{array}{l}\text { Wanita } \\
\text { pengusaha }\end{array}$ & $\begin{array}{l}\text { rasio dari wanita terhadap } \\
\text { pria sebagai pengusaha } \\
\text { sangat tinggi }\end{array}$ & $\begin{array}{l}\text { rasio dari wanita terhadap } \\
\text { pria sebagai pengusaha } \\
\text { cukup tinggi }\end{array}$ & $\begin{array}{l}\text { rasio dari wanita terhadap } \\
\text { pria sebagai pengusaha } \\
\text { sangat rendah }\end{array}$ \\
\hline
\end{tabular}

Sumber: Tambunan (2009a). 
Secara teori, hubungan antara keberadaan UMK dan kemiskinan di suatu daerah bisa "positif" atau "negatif". Positif dalam arti keberadaan UMK karena ada kemiskinan. Hal ini bisa dijelaskan sebagi berikut. Secara umum dimanapun juga, sebuah perusahaan muncul karena ada daya tarik pasar, baik pasar output (peluang untuk menjual hasil produksi) dan pasar input (peluang untuk mendapatkan input untuk berproduksi). Hubungan ini juga berlaku bagi pertumbuhan UMK. Hanya saja, di banyak negara berkembang/miskin, keberadaan pasar output dan pasar input yang membuat jumlah UMK tumbuh pesat berhubungan erat dengan kemiskinan (Gambar 1). Dari sisi pasar output, hipotesisnya adalah sebagai berikut: semakin banyak orang miskin di sebuah daerah, semakin banyak jumlah UMK di daerah itu yang memproduksi barang dan jasa dengan harga murah yang terjangkau oleh kelompok miskin. Dalam kata lain, UMK memiliki segmen pasar tersendiri, yakni pasar bagi konsumen berpendapatan rendah. Tidak ada persaingan langsung antara UMK dan UMB yang memproduksi untuk konsumen berpendapatan tinggi. Hipotesis alternatifnya adalah: semakin tinggi tingkat kesejahteraan masyarakat/rendah tingkat kemiskinan di sebuah wilayah, semakin sedikit jumlah UMK di wilayah tersebut. Jadi, di dalam kasus ini, UMK muncul atau jumlahnya bertambah karena ada faktor 'penarik', yakni adanya permintaan konsumen.

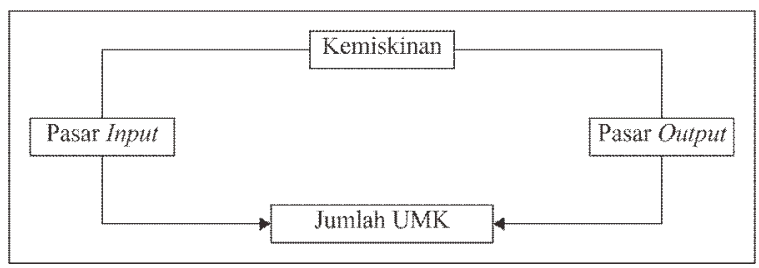

Gambar 1. Hubungan antara Kemiskinan dan Keberadaan/Pertumbuhan UMK Lewat Dua Sisi Pasar yang Berbeda.

Dari sisi pasar input, misalnya pasar tenaga kerja, semakin banyak orang miskin yang bisa disebabkan oleh banyaknya pengangguran, atau pekerja dengan upah rendah seperti pekerja harian di sektor bangunan, semakin banyak orang membuka usaha sendiri dalam skala mikro atau kecil (karena modal yang dimiliki sedikit dan pengetahuannya terbatas untuk membuka usaha lebih besar dan kompleks). Jadi, hipotesanya adalah sebagai berikut: semakin banyak pengangguran atau semakin banyak pekerja dengan upah murah, semakin banyak kemiskinan, maka semakin banyak jumlah UMK baik sebagai sumber satu-satunya pendapatan (bagi orang-orang miskin karena menganggur) atau sebagai sumber pendapatan tambahan (bagi orangorang miskin karena sumber utama pendapatannya tidak mencukupi). Di dalam kasus ini, UMK berfungsi sebagai 'penampung terakhir' (last resort) bagi orang atau keluarga miskin. UMK muncul karena ada faktor 'pendorong', yakni penawaran sumber daya manusia.

Sedangkan negatif artinya kemiskinan berkurang karena adanya UMK, dan dalam menganalisanya harus dilihat dampak keseluruhan dari keberadaan UMK, yakni lewat jalur-jalur langsung dan tidak langung, yang menciptakan efekefek penggandaan (multiplier). Jalur-jalur langsung lewat mana keberadaan UMK berdampak positif terhadap pengurangan jumlah orang miskin adalah besarnya kesempata kerja yang diciptakan oleh UMK itu sendiri (efek kesempatan kerja langsung: jalur (a) di Gambar 2) dari kegiatan produksinya. Produk yang dibuat bisa bersifat barang jadi yang dikonsumsi langsung oleh konsumen (misalnya makanan dan minuman) atau barang perantara sebagai bahan baku atau input bagi kelompok usaha lain (misalnya UMB) lewat keterkaitan produksi subcontracting (garis (c)). Dilihat dari sisi UMK, hubungan produksinya dengan UMB tidak hanya ke depan (forward linkage), tetapi juga ke belakang (backward linkage), misalnya UMK pembuat makanan membeli komoditas pertanian sebagai bahan bakunya. Maka, kesempatan kerja yang tercipta di UMB karena kegiatan produksinya yang dimungkinkan dengan adanya pasokan input dari UMK (kasus ke depan), maupun di sektor pertanian yang bisa berproduksi karena adanya permintaan dari UMK (kasus ke belakang) merupakan efek kesempatan kerja tidak langsung (garis (b)) dari keberadaan UMK. Efek kesempatan kerja tidak langsung dari keberadaan UMK juga bisa terjadi apabila para pekerja dan pemilik UMK membelanjakan pendapatan mereka untuk pembelian barang dan jasa yang dihasilkan oleh UMB (garis (d)), yang selanjutnya menjadi pendorong pertumbuhan produksi dan kesempatan kerja di kelompok usaha terakhir tersebut.

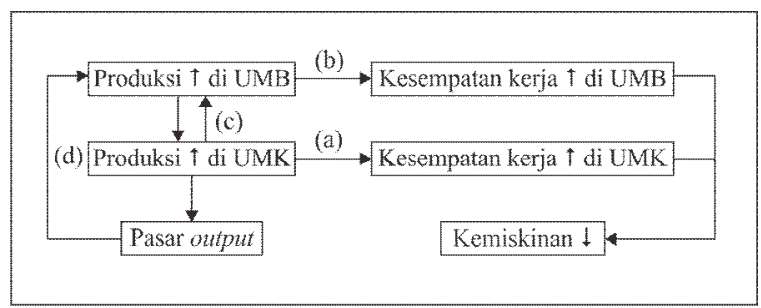

Gambar 2. Efek Penggandaan terhadap Kesempatan Kerja dari Keberadaan UMK.

Dari uraian teoretis di atas, jelas bahwa pentingnya keberadaan atau pertumbuhan UMK terhadap ekonomi dan khususnya pengurangan kemiskinan di daerah sangat tergantung pada hubungan bisnis antara UMK dan ekonomi daerah. Semakin kuat hubungan bisnis atau produksi antara UMK dengan usaha-usaha lainnya di daerah, yang artinya semakin kecil 'kebocoran ekonomi lokal', semakin besar efek penggandaan terhadap pengurangan kemiskinan di daerah, atau semakin 
banyak pengurangan jumlah orang miskin. Yang dimaksud 'kebocoran ekonomi lokal' adalah misalnya untuk berproduksi UMK di suatu daerah membeli bahan baku dari sektor hulu di luar daerah, atau UMK membuat produk perantara sebagai input bagi sektor hilir yang berlokasi di luar daerah. Jadi, bukan saja nilai tambah ekonomi lokal berkurang, kesempatan kerja yang sebenarnya bisa tercipta apabila sektor hulu dan sektor hilir tersebut berada di dalam daerah juga hilang.

Berdasarkan uraian karakateristik UMK di atas tersebut, tidak berlebihan untuk menegaskan bahwa keberadaa kelompok usaha ini sangat penting dalam upaya memerangi kemiskinan di Indonesia. Terutama dengan diberlakukannya otonomi daerah bersamaan dengan desentralisasi fiskal, upaya-upaya yang dilakukan pemerintah daerah (Pemda) atas inisiatif sendiri untuk mengurangi jumlah orang miskin di daerah menjadi sangat penting, dan UMK bisa turut berperan. Apalagi, dibanyak daerah di tanah air yang kegiatan-kegiatan ekonominya hanya berskala mikro dan kecil, sejak diterapkannya otonomi daerah UMK diharapkan bisa berperan menjadi sumber utama perkembangan dan pertumbuhan ekonomi daerah.

Tujuan utama dari studi ini bukan untuk menguji secara statistik hubungan-hubungan antara fenomena-fenomena tertentu, tetapi untuk mengeksplorasi peran usaha mikro dan kecil dalam pengentasan kemiskinan di daerah. Ada dua pertanyaan yang ingin dijawab di dalam penelitian ini. Pertama, apakah keberadaan atau pertumbuhan UMK bisa mengurangi kemiskinan di daerah? Kedua, apakah derajat pentingnya UMK bagi pengentasan kemiskinan bervariasi menurut daerah dan apa kemungkinan faktor-faktor penentunya?

\section{METODE PENELITIAN}

Sebagai sebuah penelitian yang bersifat deskriptif, studi ini didasarkan pada analisa data sekunder dengan memakai data kemiskinan dan UMK di industri manufaktur di tingkat provinsi dari
Badan Pusat Statistik (BPS), dan data lainya dari Kementerian Koperasi dan UKM, serta literatur kunci yang diseleksi. Karena memakai data BPS, maka studi ini juga memakai definisi BPS mengenai UMK berdasarkan jumlah pekerja tetap (tidak termasuk pemilik): usaha mikro (UMI) adalah unit usaha dengan pekerja antara 0 (usaha sendiri tanpa menggunakan pekerja atau di dalam literatur disebut self-employment) hingga 4 orang, dan usaha kecil (UK) antara 5 hingga 19 orang. Pentingnya keberadaan UMK terhadap pengurangan kemiskinan diukur didalam analisa ini secara tidak langsung dengan memakai sejumlah indikator, yakni jumlah unit usaha, produktivitas tenaga kerja di UMK dan pangsa output-nya.

\section{HASIL DAN PEMBAHASAN}

\section{Kemiskinan di Tingkat Provinsi}

Data nasional menunjukkan bahwa tingkat kemiskinan, yakni persentase dari jumlah penduduk yang pengeluaran per bulannya dibawah garis kemiskinan yang berlaku, di Indonesia sejak awal pemerintahan Orde Baru mengalami penurunan setiap tahun, yakni dari sekitar 40 persen pada tahun 1970 ke 17,5 persen pada tahun 1996. Pada saat ekonomi nasional dilanda sebuah krisis besar yakni krisis keuangan Asia pada periode 1997-98, tingkat kemiskinan sempat naik (akibat banyak perusahaan, khususnya perusahaan-perusahaan besar, yang terpaksa tutup atau mengurangi volume produksi karena krisis) hingga mencapai 24,2 persen pada tahun 1998, namun setelah itu mulai kembali menurun setiap tahun, dan pada tahun 2011 tercatat sebesar 12,5 persen. Namun kemiskinan per provinsi bervariasi, dan banyak provinsi yang tingkat kemiskinannya jauh di atas rata-rata nasional. Misalnya, pada tahun 2010, tingkat kemiskinan di tingkat nasional tercatat 13,3 persen, dan pada tahun itu ada 16 provinsi dengan tingkat kemiskinan di atas angkat nasional tersebut, dengan Papua sebagai provinsi paling miskin, dan DKI Jakarta paling rendah tingkat kemiskinannya sekitar 4 persen

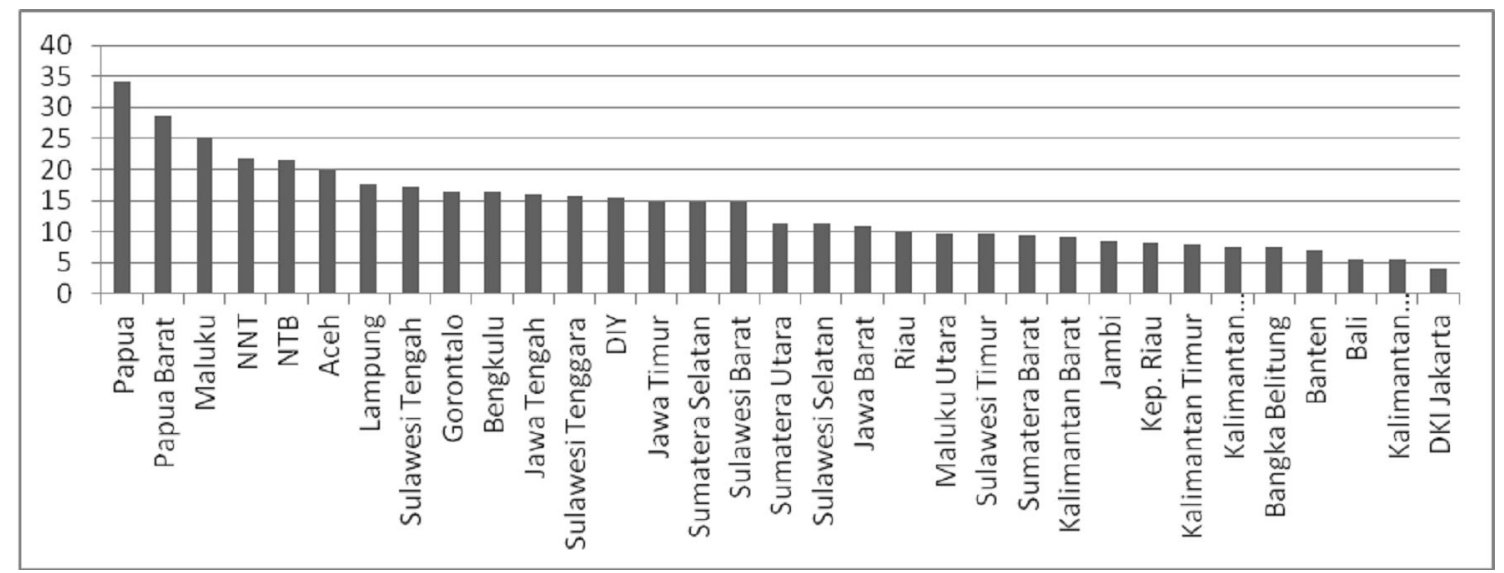

Sumber: BPS (2010a).

Gambar 3. Tingkat Kemiskinan Menurut Provinsi Tahun 2010 (\%). 


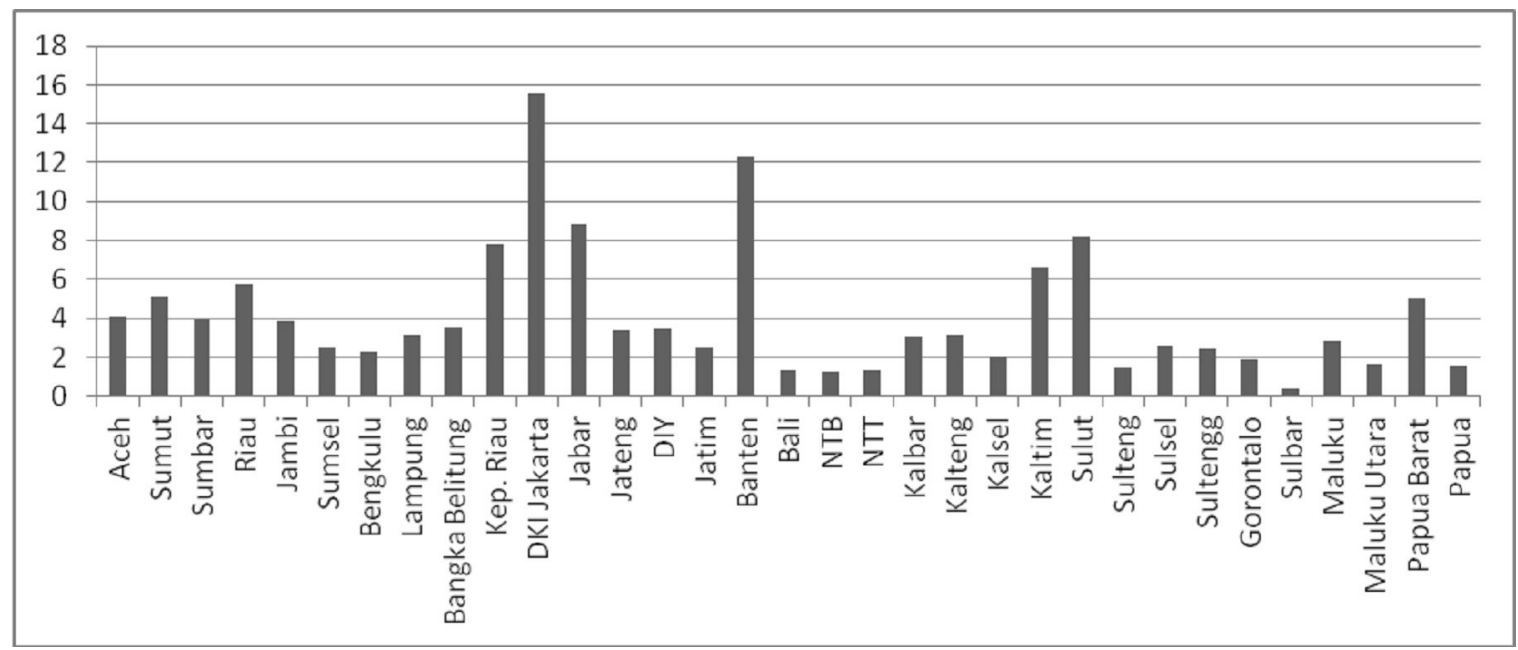

Sumber: BPS (2010a)

Gambar 4. Jumlah Pengangguran Umur 15 Tahun ke Atas menurut Provinsi Tahun 2010.

(Gambar 3).

Banyak faktor yang membuat terjadinya kemiskinan, dan perbedaan tingkat kemiskinan antar provinsi seperti yang diperlihatkan di Gambar 3 tersebut dikarenakan adanya perbedaan-perbedaan dalam faktor-faktor determinan tersebut, yang terutama adalah kesempatan kerja, terutama di sektor formal. Daerah-daerah dengan jumlah pengangguran terbuka yang tinggi biasanya juga merupakan daerah-daerah miskin. Walaupun sebagai faktor utama, namun jumlah orang yang menganggur secara resmi (pengangguran terbuka) bukanlah satu-satunya penyebab kemiskinan. Kemiskinan di suatu wilayah bisa sangat nyata walaupun jumlah orang yang tidak memiliki pekerjaan tetap di sektor formal sangat sedikit. Biasanya kemiskinan dalam kondisi seperti ini disebabkan oleh pendapatan atau upah riil pekerja yang terlalu rendah, yang dibanyak kabupaten/kota dibawah upah minimum kabupaten/kota yang berlaku. Misalnya banyak desa di Indonesia yang jenis kegiatan ekonominya pada umumnya adalah skala mikro atau kecil di sektor informal dengan pendapatan yang sangat rendah. Seperti yang dapat dilihat di Gambar 4, jumlah orang umur 15 tahun ke atas yang resmi menganggur di sektor formal menurut definisi pengangguran terbuka dari BPS paling banyak adalah di DKI Jakarta, padahal Jakarta bukan bukanlah provinsi termiskin di Indonesia (Gambar 3). Paling tidak ada dua penyebab utamanya, yakni gaji-upah rata-rata di sektor formal di DKI Jakarta lebih besar dibandingkan di wilayahwilayah lainnya yang lebih miskin. Kedua, perkembangan kegiatan ekonomi informal di DKI lebih pesat yang berarti lebih banyak menyerap penduduk kota yang tidak mendapatkan pekerjaan di sektor formal, dibandingkan di wilayah-wilayah lainnya, ditambah lagi upah rata-rata di sektor informal di DKI lebih besar daripada di sektor yang sama di wilayah-wilayah lainnya.

\section{Analisis Empiris Peran UMK}

Sebelum menganalisis peran UMK per provinsi, tidak ada salahnya membahas terlebih dahulu secara garis besar peran UMK di Indonesia. Seperti yang dapat dilihat di Tabel 2, jumlah usaha mikro, kecil dan menengah (UMKM) di Indonesia terus bertambah setiap tahunnya, dan di dalam kelompok UMKM, jumlah UMK paling banyak. Pada tahun 2000, jumlah UMK tercatat sebanyak 39 juta lebih dan pada tahun 2009 sudah mencapai 52,7 juta unit. Seperti telah dibahas sebelumnya, peran UMK paling penting adalah penyerapan tenaga kerja. Seperti yang dapat dilihat di Tabel 3, di dalam kelompok UMKM, UMK yang paling banyak menciptakan kesempatan kerja, karena memang selain sangat padat karya, kelompok usaha ini jumlahnya paling banyak dibandingkan jumlah kelompok skala lainnya.

Jumlah unit usaha dan pekerja dibayar (UMK juga banyak menggunakan anggota keluarga yang tidak digaji) bisa digunakan untuk mengukur seberapa pentingnya keberadaan UMK bagi perekonomian suatu wilayah. Walaupun sangat tergantung pada kinerja rata-rata per unit (misalnya besarnya omset atau sumbangannya terhadap pembentukan produk domestik bruto regional/PDRB), semakin banyak jumlah UMK di suatu provinsi maka dapat diasumsikan bahwa UMK semakin penting di dalam perekonomian provinsi tersebut. Demikian juga halnya dengan jumlah pekerja digaji, walaupun sangat tergantung pada pendapatan atau produktivitasnya, semakin banyak tenaga kerja yang dibayar di UMK, semakin penting keberadaan kelompok usaha tersebut.

Berdasarkan data BPS 2010, Gambar 5 menunjukkan bahwa baik jumlah unit usaha maupun jumlah pekerja di UMK di industri manufaktur digaji paling banyak terdapat di provinsi Jawa Tengah, disusul kemudian di provinsi Jawa Timur dan provinsi Jawa Barat. Satu hal yang jelas dari data ini adalah bahwa distribusi UMK, baik dalam jumlah unit usaha maupun jumlah pekerja digaji di Indonesia tidak 
Tabel 2. Jumlah Unit Usaha Menurut Skala Usaha di Semua Sektor Ekonomi di Indonesia Tahun 2000-2009 (000 Unit)

\begin{tabular}{|c|c|c|c|c|c|c|c|c|c|}
\hline Skala Usaha & 2000 & 2001 & 2003 & 2004 & 2005 & 2006 & 2007 & 2008 & 2009 \\
\hline UMK & 39.705 & $39.883,1$ & $43.372,9$ & $44.684,4$ & $47.006,9$ & $48.822,9$ & $47.720,3$ & $52.327 ., 9$ & $52.723,5$ \\
\hline UM & 78,8 & 80,97 & 87,4 & 93,04 & 95,9 & 106,7 & 120,3 & 39,7 & 41,1 \\
\hline UB & 5,7 & 5,9 & 6,5 & 6,7 & 6,8 & 7,2 & 4,5 & 4,4 & 4,7 \\
\hline Jumlah & $39.789,7$ & $39.969,9$ & $43.466,8$ & $44.784,1$ & $47.109,6$ & $48.936,8$ & $49.845,0$ & $52.262,0$ & $52.769,3$ \\
\hline
\end{tabular}

Sumber: Kementerian Koperasi dan UKM (Menegkop \& UKM) (www.depkop.go.id) dan Badan Pusat Statistik (BPS) (www.bps.go.id)

Tabel 3. Jumlah Tenaga Kerja Menurut Skala Usaha dan Sektor di Indonesia Tahun 2008 (Pekerja)

\begin{tabular}{lrrrrr}
\hline Sektor & UMI & UK & UM & UB & Jumlah \\
\hline Pertanian & 41.749 .303 & 66.780 & 643.981 & 229.571 & 42.689 .635 \\
Pertambangan & 591.120 & 28.762 & 21.581 & 78.847 & 720.310 \\
Industri & 7.853 .435 & 1.145 .066 & 1.464 .915 & 1.898 .674 & 12.362 .090 \\
Listrik, gas \& air bersih & 51.583 & 19.917 & 31.036 & 54.233 & 156.769 \\
Bangunan & 576.783 & 137.555 & 51.757 & 31.016 & 797.111 \\
Perdagangan, hotel \& rumah & 22.168 .835 & 1.672 .351 & 472.876 & 179.895 & 24.493 .957 \\
makan & 3.496 .493 & 145.336 & 111.854 & 98.191 & 3.851 .874 \\
Transportasi \& komunikasi. & 2.063 .747 & 313.921 & 279.877 & 156.064 & 2.813 .609 \\
Keuangan, persewaan \& jasa & 5.096 .412 & 462.683 & 178.311 & 49.723 & 5.787 .129 \\
Jasa lainnya & & & & & \\
& 83.647 .711 & 3.992 .371 & 3.256 .188 & 2.776 .214 & 93.672 .484 \\
Jumlah & & & & & \\
\hline
\end{tabular}

Sumber: Menegkop \& UKM (www.depkop.go.id) dan BPS (www.bps.go.id)

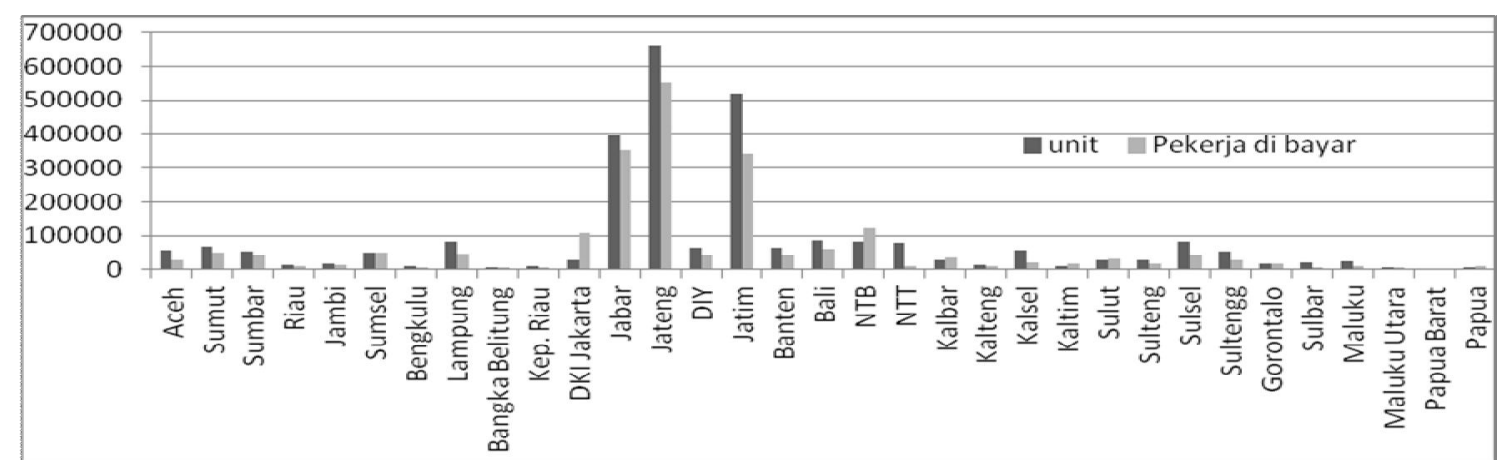

Sumber: BPS (2010a)

Gambar 5. Jumlah Unit dan Tenaga Kerja Dibayar di UMK di Industri Manufaktur Menurut Provinsi Tahun 2010.

seimbang; lebih banyak terdapat di wilayah Indonesia bagian barat, khususnya pulau Jawa dan Bali.

Salah satu ciri UMK di industri manufaktur di Indonesia adalah bahwa mereka dari kelompok industri yang sama berlokasi berdekatan satu sama lainnya di suatu wilayah. Pengelompokan secara geografis menurut kelompok industri ini, di dalam literatur industr disebut klaster. Di Indonesia, banyak kegiatan UMK yang tersebar di daerah-daerah memang sudah berlangsung turun-temurun, dan umumnya setiap daerah memiliki spesialisasi UMK tersendiri. Misalnya klaster-klaster UMK di Jepara, Cirebon dan Solo (Provinsi Jawa Tengah) terkenal dengan spesialisasi pembuatan meubel dari kayu dan rotan. Data dari
Kementerian Koperasi dan UKM juga menunjukkan bahwa sebagian besar dari jumlah klaster UMK yang tercatat ada di Indonesia berlokasi di Jawa (Gambar 6).

Sekarang pertanyaannya: apakah sebaran jumlah unit usaha dan pekerja dibayar di UMK menurut provinsi tersebut berkaitan erat dengan penyebaran kemiskinan yang juga berbeda antar provinsi, sesuai teori "keberadaan UMK karena adanya kemiskinan" seperti yang telah dibahas sebelumnya? Jawabannya adalah: ada suatu keterkaitan yang erat. Memang tingkat kemiskinan atau persentase penduduk yang hidup di bawah garis kemiskinan yang berlaku di pulau Jawa jauh lebih rendah daripada di wilayah Indonesia bagian timur 


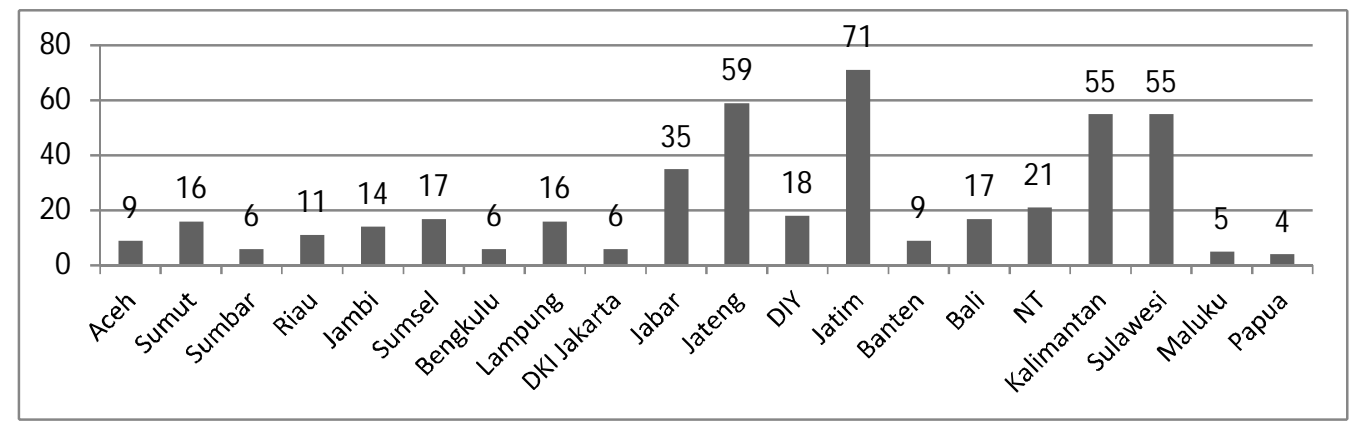

Sumber: Menegkop \& UKM (www.depkop.go.id).

Gambar 6. Sebaran Klaster UMK di Industri Manufaktur di Indonesia Menurut Wilayah Tahun 2005 (unit).

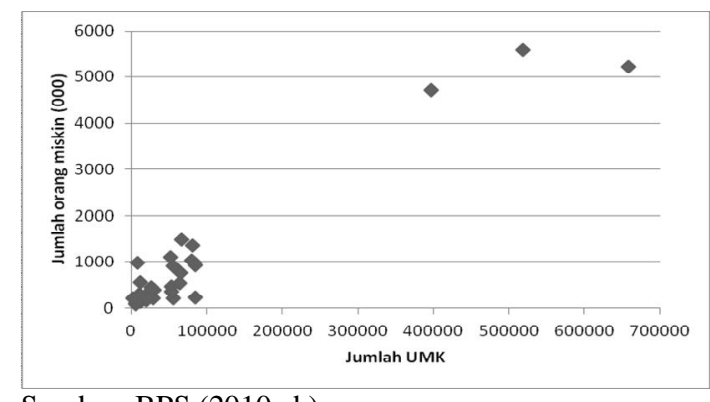

Sumber: BPS (2010a,b)

Gambar 7. Sebaran Titik Kombinasi Jumlah Orang Miskin dan Jumlah UMK Per Provinsi.

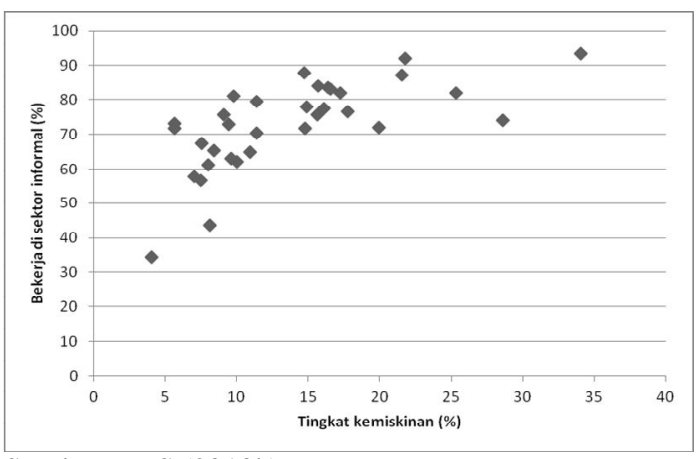

Sumber: BPS (2010b)

Gambar 8. Sebaran Titik Kombinasi Tingkat Kemiskinan dan Tingkat Kesempatan Kerja di Sektor Informal Per Provinsi Tahun 2010 (\%).

(lihat Gambar 3), tetapi jumlah orang miskin di pulau Jawa jauh lebih dibandingkan jumlah orang miskin di misalnya Papua karena penduduk Indonesia terkonsentrasi di pulau Jawa. Hal ini bisa dilihat di tiga gambar berikut: Gambar 7 yang menunjukkan sebaran titik kombinasi antara jumlah orang miskin dan jumlah UMK per provinsi, Gambar 8 yang menunjukkan sebaran titik kombinasi antara jumlah tingkat kemiskinan dan persentase penduduk berumur 15 tahun ke atas yang bekerja di sektor

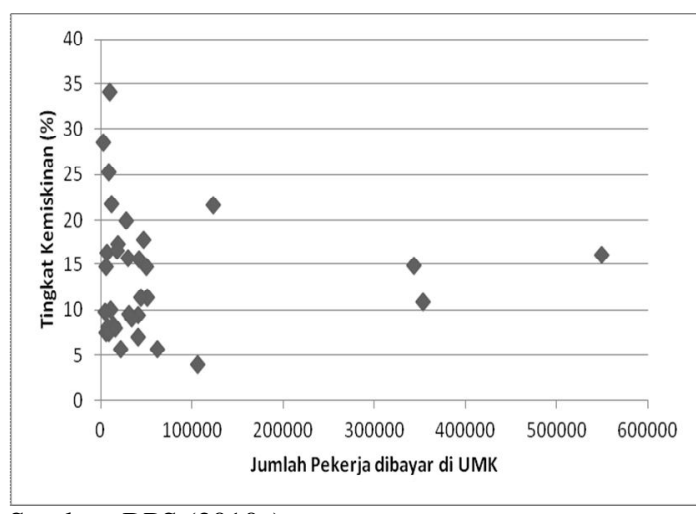

Sumber: BPS (2010a)

Gambar 9. Sebaran Titik Kombinasi Tingkat Kemiskinan dan Jumlah Pekerja Digaji di UMK Per Provinsi Tahun 2010 (\%).

informal per provinsi (sektor informal adalah kegiatan-kegiatan ekonomi tidak resmi atau tidak tercatat, tidak membayar pajak, banyak yang tidak berlokasi tetap atau tidak resmi, berskala mikro dan kecil dengan pendapatan yang pada umumnya sangat rendah), dan Gambar 9 yang memperlihatkan sebaran titik kombinasi antara tingkat kemiskinan dan jumlah pekerja digaji di UMK. Dua gambar pertama tersebut mempunyai kesamaan yakni memiliki garis tren dengan sudut positif yang memberi kesan sebagai berikut: (1) semakin banyak jumlah orang miskin jumlah UMK cenderung semakin banyak (Gambar 7), dan (2) semakin besar tingkat kemiskinan jumlah penduduk yang bekerja di sektor informal cenderung meningkat (Gambar 8). Seperti yang telah dibahas di dalam teori, banyaknya orang miskin menimbulkan dua insentif bagi tumbuhnya kegiatan-kegiatan UMK, yakni lewat pasar output: orang-orang miskin tidak sanggup membeli barang-barang kebutuhan pokok di pasar modern karena harganya mahal maka permintaan meningkat terhadap barang-barang yang sama buatan UMK dengan kualitas lebih rendah namun lebih murah, dan lewat pasar input: untuk mendapatkan 
Tabel 4. Produktivitas UMK di Industri Manufaktur menurut Provinsi Tahun 2010 (juta rupiah)

\begin{tabular}{lrr}
\hline Provinsi & Produktivitas unit usaha & Productivitas tenaga kerja \\
\hline (1)Aceh & 71,065 & 140,581 \\
(2)Sumatera Utara & 79,149 & 102,568 \\
(3)Sumatera Barat & 78,963 & 101,289 \\
(4)Riau & 95,199 & 111,484 \\
(5)Jambi & 71,64 & 097,452 \\
(6)Sumatera Selatan & 110,924 & 113,473 \\
(7)Bengkulu & 74,909 & 102,514 \\
(8)Lampung & 50,21 & 086,209 \\
(9)Bangka Belitung & 106,071 & 099,553 \\
(10)Kep. Riau & 68,338 & 101,15 \\
(11)DKI Jakarta & 273,329 & 73,717 \\
(12)Jawa Barat & 77,824 & 87,406 \\
(13)Jawa Tengah & 63,895 & 76,601 \\
(14)DIY & 55,001 & 82,344 \\
(15)Jawa Timur & 68,538 & 103,441 \\
(16)Banten & 46,461 & 73,826 \\
(17)Bali & 77,354 & 105,679 \\
(18)NTB & 70,397 & 47,515 \\
(19)NTT & 18,219 & 128,664 \\
(20)Kalimantan Barat & 66,64 & 57,184 \\
(21)Kalimantan Tengah & 82,644 & 135,646 \\
(22)Kalimantan Selatan & 37,372 & 94,943 \\
(23)Kalimantan Timur & 154,947 & 117,751 \\
(24)Sulawesi Utara & 87,913 & 81,181 \\
(25)Sulawesi Tengah & 39,003 & 55,396 \\
(26)Sulawesi Selatan & 62,254 & 119,634 \\
(27)Sulawesi Tenggara & 43,992 & 79,601 \\
(28)Gorontalo & 43,698 & 46,585 \\
(29)Sulawesi Barat & 31,531 & 120,603 \\
(30)Maluku & 33,48 & 99,65 \\
(31)Maluku Utara & 107,645 & 123,113 \\
(32)Papua Barat & 150,526 & 86,431 \\
(33)Papua & 201,097 & 87,702 \\
Indonesia & 68,691 & \\
\hline
\end{tabular}

Sumber: BPS (2010a)

sekedar pendapatan atau pendapatan tambahan, banyak orang miskin membuka usaha sendiri. Sedangkan Gambar 9 berkorelasi negatif yang memberi kesan bahwa semakin banyak pekerja digaji di UMK semakin rendah tingkat kemiskinan.

Pentingnya keberadaan UMK bagi pengurangan kemiskinan juga dapat dilihat dari tingkat produktivitas di UMK, yakni rasio nilai tambah per unit usaha atau/dan rasio nilai tambah per pekerja. Salah satu hipotesis dari hubungan antara tingkat produktivitas UMK dan tingkat kemiskinan adalah: semakin tinggi produktivitas UMK, yang berarti semakin efisien UKM berproduksi, semakin besar besar pendapatan di UMK baik rata-rata pendapatan per unit usaha maupun rata-rata pendapatan per pekerja, semakin rendah kemiskinan. Tentu dengan asumsi bahwa faktor-faktor berpengaruh lainnya terhadap tingkat pendapatan tidak berubah. Seperti telah dibahas sebelumnya, dasar teorinya adalah bahwa kemiskinan di suatu wilayah tidak selalu disebabkan oleh banyaknya jumlah orang tanpa pekerjaan tetap (pengangguran terbuka), tetapi juga sering kali karena rendahnya pendapatan per pekerja yang disebabkan oleh rendahnya produktivitas pekerja.

Data BPS 2010 mengenai UMK di industri manufaktur menunjukkan bahwa produktivitas baik per unit maupun per pekerja (yang dibayar) tidak homogeny antar provinsi (Tabel 4). Banyak provinsi di mana produktivitas UMK-nya lebih rendah dibandingkan angka rata-rata pada tingkat nasional. Namun yang paling menarik dari data ini adalah bahwa di sejumlah provinsi di Indonesia bagian timur, produktvitasnya lebih baik dibandingkan pada tingkat nasional. Perbedaan tersebut dikarenakan adanya perbedaan-perbedaan dalam faktor-faktor lokal seperti misalnya harga jual (karena produktivitas diukur berdasarkan nilai tambah atau pendapatan pada harga-harga yang berlaku), rasio antara jumlah pekerja yang digaji dengan jumlah peekrja yang tidak dibayar (karena di dalam analisa ini yang dibahas hanya produktivitas tenaga kerja yang dibayar), konsentrasi industri dari UMK (karena data BPS juga menunjukkan bahwa produktivitas UKM berbeda menurut kelompok industri), kondisi internal perusahaan termasuk kendala-kendalanya seperti kekurangan modal untuk 


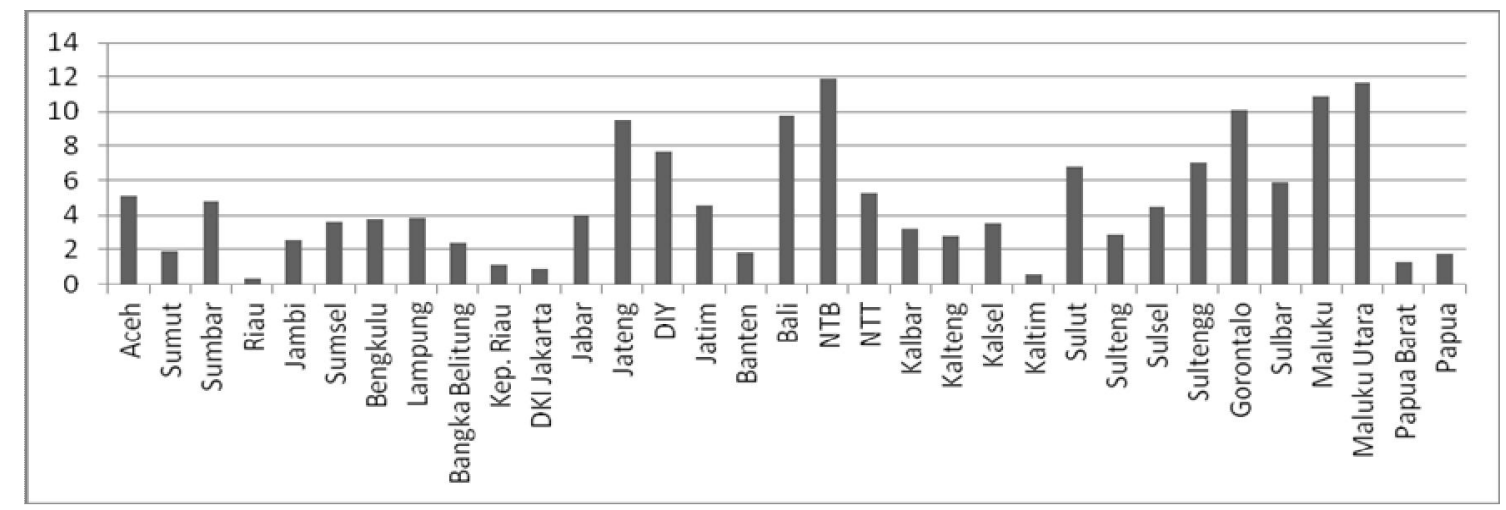

Sumber: BPS (2010a)

Gambar 10. Pangsa PDRB UMK di Industri Manufaktur menurut Provinsi Tahun 2010.

membeli mesin atau alat-alat produksi, keterampilan pekerja, pola produksi, dan masih banyak lagi faktor lain.

Mungkin indikator terbaik mengenai peran sebuah sektor atau industri terhadap ekonomi suatu wilayah adalah sumbangan dari sektor/industri tersebut terhadap pembentukan atau pertumbuhan output agregat di wilayah tersebut (walaupun ada kelemahan dari indikator tersebut; terutama karena kegiatan-kegiatan ekonomi informal tidak tercatat dalam PDRB). Dalam kasus UMK adalah pangsa nilai outputnya terhadap nilai produk domestik regional bruto (PDRB). Dasar teorinya atau hipotesisnya adalah sebagai berikut: semakin besar pangsa PDRB dari UMK semakin besar efek penggandaan dari keberadaan kelompok usaha tersebut terhadap ekonomi provinsi, ceteris paribus. Namun besarnya efek penggandaan itu sendiri tidak harus berkorelasi positif dengan besarnya pangsa PBRB, karena efek tersebut sangat tergantung pada besarnya keterkaitan produksi ke depan maupun ke belakang antara UMK dengan UMB di semua sektor ekonomi, dan ketergantungan pendapatan antara UMK dengan masyarakat (konsumen). Dalam kata lain, UMK dengan sumbangan PDRB yang rendah di suatu daerah bisa saja mempunyai efek penggandaan yang lebih besar daripada UMK di daerah lain yang pangsa output agregatnya lebih besar. Hal ini bisa terjadi karena kelompok UMK pertama tersebut memiliki keterkaitan yang lebih besar dengan ekonomi lokal (impor UMK maupun impor total daerah lebih rendah) dibandingkan kelompok UMK kedua tersebut.

Data BPS 2010 menunjukkan bahwa pangsa PDRB dari UMK di industri manufaktur bervariasi menurut provinsi (Gambar 10). Yang menarik dari data ini adalah secara rata-rata kontribusi output UMK terhadap pembentukan PDRB lebih besar di Indonesia bagian timur dibandingkan di bagian barat, padahal jumlah unit usaha lebih banyak di pulau Jawa dan Bali. Sangat mungkin sekali karena di provinsi-provinsi di bagian timur seperti Nusa Tenggara, Maluku dan Maluku Utara, derajat diversifikasi dari kegiatan ekonominya sangat rendah, yang terkonsentrasi di kelompok-kelompok industri yang didominasi oleh UMK (yang jumlah UMB relatif kecil). Sedangkan di Papua Barat dan Papua, sektor pertambangan mendominasi perekonomian mereka yang dengan sendirinya menghasilkan pangsa PDRB paling besar dibandingkan dengan sektor-sektor ekonomi lainnya, dan di dalam perekonomian DKI Jakarta, sektor jasa (termasuk keuangan) paling dominan dengan jumlah UMB tidak hanya lebih banyak dibandingkan jumlah UMK tetapi juga total nilai outputnya lebih besar.

Indikator lainnya yang juga sangat bagus untuk mengukur secara potensial pentingnya keberadaan UMK bagi pengurangan kemiskinan di daerah adalah nilai ekspor UMK. Dasar teorinya adalah sebagai berikut: semakin banyak UMK di suatu wilayah yang melakukan ekspor, semakin besar pendapatan UMK (semakin besar sumbangannya terhadap PDRB), semakin besar efek positifnya terhadap peningkatan kesempatan kerja atau penurunan kemiskinan di wilayah itu, dengan asumsi bahwa faktor-faktor penentu lainnya tidak berubah. Lebih menguntungkan bagi UMK melakukan ekspor daripada menjual ke pasar lokal terutama karena harga di pasar luar negeri biasanya lebih besar daripada harga di pasar lokal. Sebenarnya yang lebih bagus adalah pangsa UMK di dalam total ekspor daerah. Namun karena tidak ada data mengenai jumlah ekspor per provinsi (dan juga sulit memastikan apakah data ekspor dari suatu provinsi benar-benar berasal dari provinsi tersebut, atau kiriman dari provinsi lain yang tidak memiliki pelabuhan laut atau udara untuk pengiriman), maka nilai ekspor UMK per provinsi dapat digunakan sebagai alternatifnya.

Namun sekarang pertanyaannya adalah sejauh mana UMK Indonesia terlibat dalam kegiatan ekspor? Jawabannya, tidak terlalu besar. Bahkan dapat dikatakan bahwa salah satu ciri utama dari UMK Indonesia seperti pada umumnya di negaranegara berkembang (berbeda dengan UMK di negara-negara maju) adalah bahwa sebagian besar UMK Indonesia berorientasi pasar dalam negeri. Banyak alasan kenapa demikian, dan yang paling 


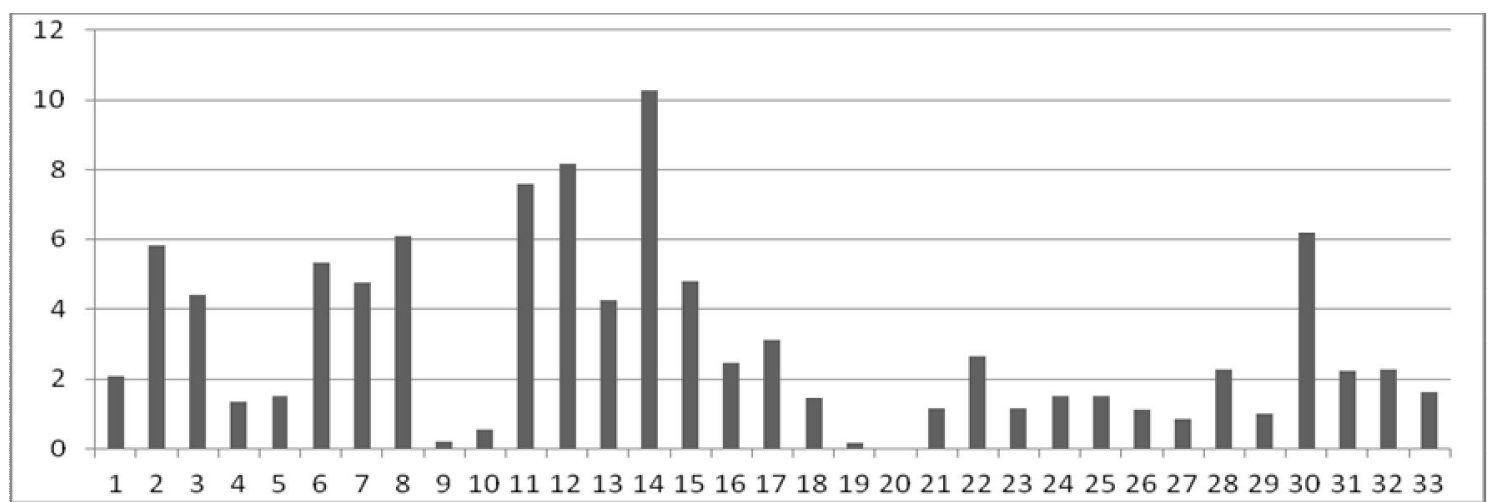

Catatan: nomor urut provinsi, lihat Tabel 1

Sumber: BPS (2010)

Gambar 11. Persentase dari UMK Berorientasi Pasar Domestik dengan Pemasaran Lintas Provinsi menurut Provinsi Tahun 2010.

Tabel 5. Nilai Ekspor Non-migas Indonesia Menurut Skala Usaha Tahun 2006-2009 (Miliar Rp/Juta Dollar AS)

\begin{tabular}{lrrrrr}
\hline \multirow{2}{*}{ Tahun } & \multicolumn{5}{c}{ Nilai Ekspor Non-migas } \\
\cline { 2 - 6 } & \multicolumn{1}{c}{ UMI } & UK & UM & \multicolumn{1}{c}{ UB } & \multicolumn{1}{c}{ Total } \\
\hline \multirow{2}{*}{2006} & Rp13.477,2 & Rp29.365,4 & Rp79.108,2 & Rp656.231,8 & Rp778.182,6 \\
& US\$1.347,7 & US\$2.936,5 & US\$7.910,8 & US\$65.623,2 & US\$77.818,3 \\
2007 & Rp15.024,9 & Rp34.661,8 & Rp93.325,7 & Rp749.999,9 & Rp893.012,3 \\
& US $\$ 1.502,5$ & US\$3.466,2 & US\$9.332,6 & US\$75.000,0 & US\$89.201,2 \\
2008 & Rp 20.247,2 & Rp44.148,3 & Rp119.363,6 & Rp915.091,2 & Rp1.098.850,2 \\
& US\$2.024,7 & US\$4.414,8 & US\$11.936,4 & US\$91.509,1 & US\$109.885,0 \\
2009 & Rp 14.375,3 & Rp36.839,7 & Rp 111.039,6 & Rp790.835,3 & Rp953.089,9 \\
& US\$1.597,26 & US\$4.093,3 & US\$12.337,7 & US\$87.870,6 & US\$105.898,9 \\
\hline
\end{tabular}

Sumber: Kementerian Koperasi dan UKM (www.depkop.go.id)

utama adalah keterbatasan atas empat input kunci, yakni: (1) Teknologi dan keahlian tenaga kerja dan pemilik usaha/pengusaha (mereka tidak mampu menghasilkan barang-barang yang memenuhi standar kualitas internasional sehingga berdaya saing global yang tinggi); (2) Informasi khususnya mengenai peluang-peluang pasar yang ada (termasuk perubahan-perubahan yang sedang berlangsung dalam permintaan pasar/selera masyarakat); (3) Strategis-strategis bisnis global; dan (4) Modal untuk membiayai kegiatan-kegiatan ekspor. Untuk kebanyakan UMK, melakukan pemasaran internasional sangat mahal, karena melibatkan banyak kegiatan mulai dari promosi, distribusi, komunikasi, mendapatkan lisensi ekspor, hingga transportasi dan logistik.

Data BPS 2010 memberikan tiga kategori UMK di industri manufaktur menurut orientasi pasar, yakni hanya melayani pasar dalam negeri, hanya melayani pasar ekspor, dan melayani pasar domestik dan luar negeri. Dalam kategori pertama, ternyata banyak UMK yang hanya menjual produknya ke pasar-pasar di kabupaten atau kota yang sama; bahkan banyak dari mereka, terutama UMI, hanya melayani pasar di desa yang sama. Pada dasarnya, alasan utamanya sama seperti kenapa tidak banyak UMK yang melakukan ekspor, yakni keterbatasan dana untuk melakukan pemasaran yang lebih luas yang berarti proses pemasarannya lebih ruwet dan mahal, keterbatasan pengetahuan mengenai pasarpasar di luar desa/kabupaten/kota (yang terutama disebabkan oleh keterbatasan informasi), dan keterbatasan infrastruktur dan fasilitas transportasi yang efisien yang menghubungi mereka dengan pasar-pasar di wilayah-wilayah yang jauh.

Berdasarkan data BPS 2010, Gambar 11 menunjukkan paling sedikit satu hal yang sangat menarik, yakni walaupun tidak ada satupun provinsi yang UMK-nya hanya melayani pasar luar negeri (atau dalam perkataan lain, di semua provinsi menjual sepenuhnya ke pasar domestik adalah kategori UMK menurut orientasi pasar yang dominan di Indonesia), proporsi dari UMK yang menjual ke pasar-pasar di luar provinsinya (yang dapat dikategorikan sebagai UMK berorientasi pasar nasional) hanya sekitar 10 persen, dan seperti yang dapat dilihat hanya UMK di D.I. Yogyakarta yang mencapai angka tersebut.

Seperti telah disinggung sebelumnya, salah satu karakteristik penting dari UMK di Indonesia adalah bahwa sebagian besar dari kelompok usaha tersebut berorientasi pasar dalam negeri. Namun demikian, ini tidak mengatakan bahwa secara nasional nilai ekspor UMK sangat kecil untuk diperhitungkan di dalam total ekspor Indonesia atau ekspornya tidak tumbuh setiap tahun. Berdasarkan 
data pemerintah yang ada ((dari Kementerian Koperasi dan UKM dan/atau Kementerian Perdagangan), di kelompok-kelompok industri tertentu, banyak UMK melakukan ekspor dan meningkat setiap tahun, seperti yang ditunjukkan di Tabel 5. Yang menarik dari tabel ini adalah bahwa di dalam kelompok UMK nilai ekspor UK setiap tahunnya lebih besar dibandingkan nilai ekspor UMI. Demikian juga nilai ekspor UMK secara total selalu lebih kecil dibandingkan nilai ekspor UM, dan yang paling besar selalu dari UB. Struktur ekspor menurut skala usaha ini memberi kesan adanya suatu korelasi positif antara skala usaha dan besarnya nilai ekspor, yang mau mengatakan bahwa semakin besar skala usaha semakin besar kemampuan melakukan ekspor.

Memang, jika dilihat secara relatif pangsa UMK di dalam nilai total ekspor non-migas Indonesia atau di dalam nilai total ekspor dari industri manufaktur (termasuk ekspor dari UMB) memang tetap lebih kecil dibandingkan sumbangan UMB. Misalnya, pada awal dekade 90-an, kontribusi UMK terhadap nilai total ekspor Indonesia (tidak termasuk minyak dan gas) tercatat sekitar hanya 11,1 persen, dan pada tahun 2008 naik hingga mendekati 20 persen, dibandingkan sekitar 80 persen saham UMB. Sekali lagi, struktur ini menandakan bahwa kemampuan UMK melakukan ekspor masih rendah dibandingkan rekannya UMB, dan kelemahan tersebut disebabkan oleh banyak faktor yang telah dibahas sebelumnya. Pada umumnya UMK yang melakukan ekspor adalah di industry-industri makanan dan minuman, meubel, produk-produk lainnya dari kayu, bambu dan rotan, pakaian jadi, alas kaki, dan kerajinan seperti ukir-ukiran dan souvenir.

UMK di industri yang sama cenderung berlokasi saling berdekatan di wilayah yang sama, atau cenderung membentuk klaster, dan ini juga merupakan salah satu karakteristik penting dari UMK di Indonesia (seperti juga di negara-negara lain). UMK cenderung membentuk klaster-klaster yang bisa mencakup lebih dari satu desa, dan juga banyak terdapat di pinggiran-pinggiran kota-kota besar seperti DKI Jakarta dan Surabaya. Kebanyakan dari klaster-klaster UMK yang ada di Indonesia sudah ada sejak zaman kolonialisasi Belanda yang

Tabel 6. Klaster-klaster dari UMKM di Industri Manufaktur yang Berorientasi Ekspor di Indonesia Menurut Provinsi Tahun 2005

\begin{tabular}{|c|c|c|c|c|}
\hline \multirow[b]{2}{*}{ Provinsi } & \multirow{2}{*}{$\begin{array}{l}\text { Jumlah klaster } \\
\text { (yang ekspor dan } \\
\text { tidak ekspor) }\end{array}$} & \multicolumn{3}{|c|}{ Klaster-klaster yang ekspor } \\
\hline & & Jumlah klaster & $\begin{array}{c}\text { Jumlah unit } \\
\text { usaha }\end{array}$ & $\begin{array}{l}\text { Jumlah } \\
\text { pekerja }\end{array}$ \\
\hline Nanggroe Aceh Darussalam & 9 & 2 & 68 & 205 \\
\hline Sumatra Utara & 16 & 5 & 211 & 724 \\
\hline Sumatra Barat & 6 & t.a.d* & t.a.d & t.a.d \\
\hline Riau & 11 & 3 & 166 & 367 \\
\hline Jambi & 14 & 4 & 182 & 580 \\
\hline Sumatra Selatan & 17 & t.a.d & t.a.d & t.a.d \\
\hline Bengkulu & 6 & 1 & 36 & 109 \\
\hline Lampung & 16 & 4 & 206 & 530 \\
\hline Jakarta & 6 & 2 & 210 & 295 \\
\hline Jawa Barat & 35 & 11 & 593 & 2292 \\
\hline Jawa Tengah & 59 & 20 & 1558 & 7803 \\
\hline D.I.Yogyakarta & 18 & 8 & 600 & 1676 \\
\hline Jawa Timur & 71 & 10 & 499 & 1976 \\
\hline Banten & 9 & 1 & 55 & 388 \\
\hline Bali & 17 & 7 & 515 & 1484 \\
\hline NTB & 15 & 6 & 509 & 4635 \\
\hline NTT & 6 & 3 & 99 & 412 \\
\hline Kalimantan Barat & 10 & 1 & 30 & 91 \\
\hline Kalimantan Tengah & 11 & t.a.d & t.a.d & t.a.d \\
\hline Kalimantan Selatan & 17 & 1 & 50 & 150 \\
\hline Kalimantan Timur & 17 & 2 & 73 & 250 \\
\hline Sulawesi Utara & 3 & t.a.d & t.a.d & t.a.d \\
\hline Sulawesi Tengah & 11 & t.a.d & t.a.d & t.a.d \\
\hline Sulawesi Selatan & 26 & t.a.d & t.a.d & t.a.d \\
\hline Sulawesi Tenggara & 6 & 2 & 80 & 205 \\
\hline Gorontalo & 5 & t.a.d & t.a.d & t.a.d \\
\hline Sulawesi Barat & 4 & 1 & 69 & 90 \\
\hline Maluku & 4 & t.a.d & t.a.d & t.a.d \\
\hline Maluku Utara & 1 & t.a.d & t.a.d & t.a.d \\
\hline Papua Barat & 1 & t.a.d & t.a.d & t.a.d \\
\hline Papua & 3 & 1 & 30 & 90 \\
\hline
\end{tabular}

Catatan: t.a.d: tidak ada data

Sumber: Kementerian Koperasi dan UKM (www.depkop.go.id) 


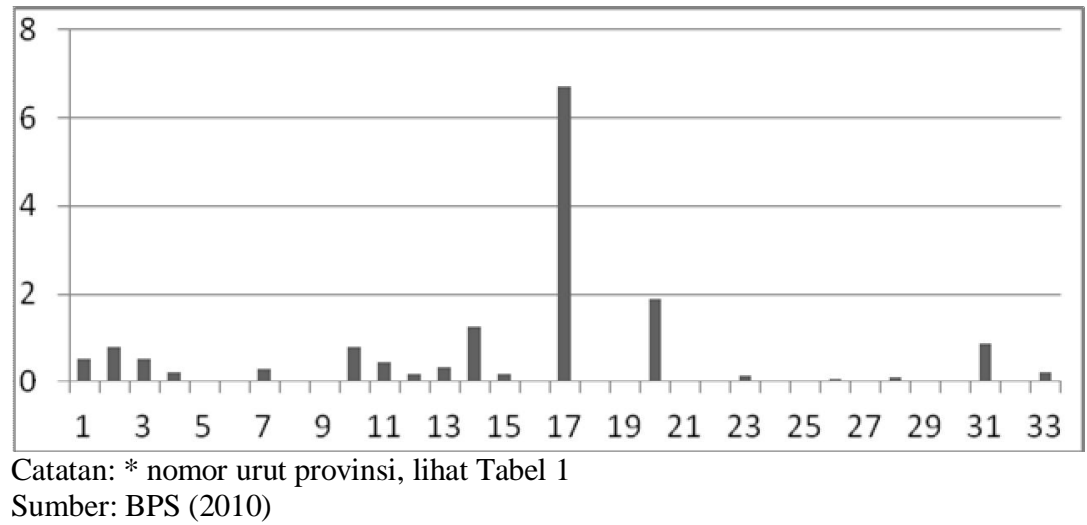

Gambar 12. Persentase dari UMK yang Melakukan Ekspor Sepenuhnya menurut Provinsi Tahun 2010.

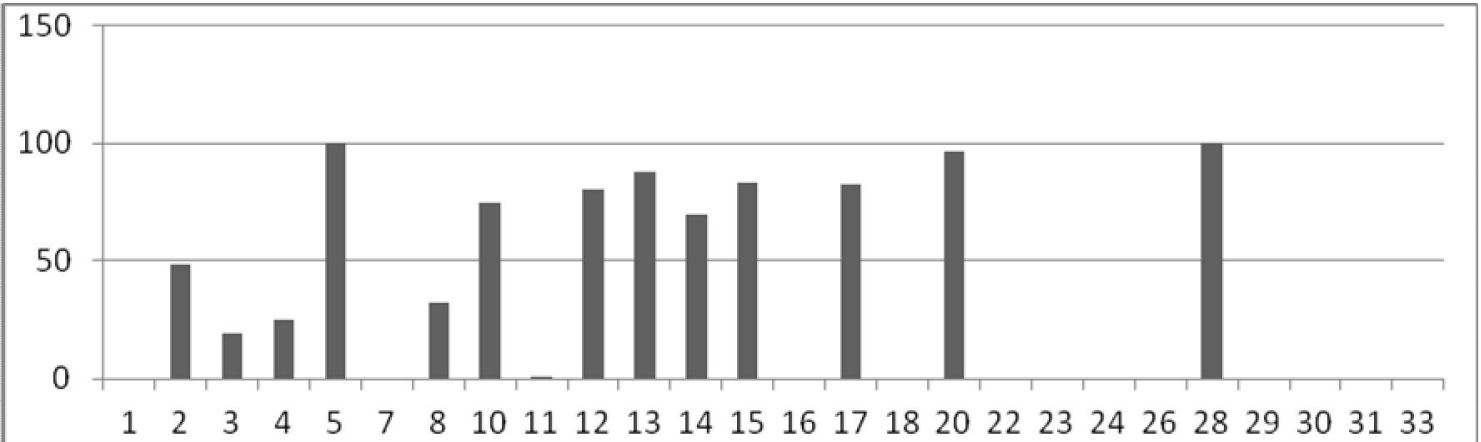

Catatan: * nomor urut provinsi, lihat Tabel 1

Sumber: BPS (2010)

Gambar 13. Persentase dari UMK yang Mengekspor 80 Persen atau Lebih dari Total Produksinya menurut Provinsi yang punya UMK Berorientasi Ekspor Tahun 2010.

sudah melewati lebih dari dua generasi seperti meubel rotan di Tasikmalaya (Provinsi Jawa Barat) dan meubel kayu di Jepara (Provinsi Jawa Tengah), dan banyak dari klaster-klaster tersebut mendapat bimbingan dari pemerintah dalam berbagai macam bentuk terutama penyediaan fasilitas-fasilitas umum yang dapat digunakan oleh semua pengusaha di dalam klaster seperti mesin-mesin dan laboratorium untuk pengujian kualitas produk. Berdasarkan data yang ada dari Kementerian Koperasi dan UKM, pada tahun 2005 saja tercatat ada 450 klaster dari UMKM (tidak ada data khusus UMK) di industri manufaktur yang dibina oleh pemerintah, dan beberapa dari klaster tersebut berorientasi ekspor. Seperti yang ditunjukkan di Tabel 6, pulau Jawa tidak hanya memiliki proporsi terbesar dari jumlah klaster UMKM yang ada tetapi juga dari jumlah klaster UMKM yang berorientasi ekspor. Fakta ini memberi suatu kesan bahwa UMKM di pulau Jawa lebih berorientasi ekspor dibandingkan rekannya di wilayah lain di Indonesia.

Mungkin dapat dikatakan bahwa diantara klaster-klaster UMK yang berorientasi ekspor yang ada di Indonesia yang paling terkenal dan paling maju adalah klaster meubel kayu di Jepara di Provinsi Jawa Tengah. Pada pertengahan dekade 80- an banyak UMK di klaster tersebut mulai melakukan ekspor untuk pertama kalinya, dan tercatat bahwa 10 besar unit usaha yang ekspor menguasai hampir 50 persen dari nilai total ekspor dari klaster tersebut. Awalnya laju pertumbuhan ekspor per tahun dari klaster tersebut tidak terlalu pesat, namun gebrakan paling besar muncul setelah sejumlah produsen mebel dari Jepara mengikuti sebuah pameran besar mengenai barang-barang ekspor Indonesia di Bali pada tahun 1989, dan sejak itu dalam waktu yang relatif singkat meubel dari berbagai jenis yang dihasilkan Jepara menjadi sangat popular baik di kalangan pembeli dalam negeri maupun di luar negeri. Awalnya, ekspor meubel dari Jepara hanya ditujukan pada segmen pasar konsumen berpendapatan rendah di negara-negara tujuan, namun menjelang dekade 90-an meubel Jepara mulai menggarap pasar luar negeri untuk masyarakat berpendapatan menengah dan tinggi. Akibat bagusnya ekspor mereka, pada saat permintaan domestik merosot tajam pada periode krisis keuangan Asia 1997/98, para produsen meubel di Jepara tidak terlalu merasakan dampak negatif dari krisis tersebut. Namun sejak krisis tersebut, eksportir-eksportir meubel kayu dari Jepara mulai mendapatkan persaingan yang semakin sengit dari 
produsen-produsen meubel dari sejumlah negara tetangga terutamas China, Vietnam dan Kambodia. Banyak faktor yang membuat kinerja ekspor dari UMK meubel di Jepara begitu baik, diantaranya adalah perbaikan pelabuhan laut di Semarang yang memfasilitasikan transportasi dari lokasi klaster ke pelabuhan, semakin baiknya fasilitas-fasiltas pendanaan, dan besarnya partisipasi dari pihak-pihak di negara-negara pembeli, mulai dari pembelipembeli individual (konsumen), pedagang, importir, pemilik grosir hingga industry-industri terkait. Tetapi sumber paling utama yang membuat meubel Jepara menjadi sangat terkenal di dunia adalah peran dari wisatawan-wisatawan asing yang berkunjung ke Jepara. Bahkan menurut beberapa sumber (a.l. Sandee dan Wingel (2002) dan Tambunan (2012)), wisatawan-wisatawan asing menyumbang sekitar 25 persen dari nilai total ekspor meubel Jepara pada periode sebelum krisis keuangan Asia 1997/98. Peran mereka adalah sebagai penghubung/mediator utama antara produsen dengan konsumen di luar negeri. Bahkan mereka juga yang membina UMK meubel di Jepara terutama mengenai selera konsumen di negara-negara mereka dan disain-disain apa yang paling digemari.

Selain itu sumber-sumber tersebut juga menunjukkan bahwa dampak dari kemajuan klaster meubel di Jepara terhadap kesempatan kerja sangat signifikan, apalagi jika juga diperhitungkan efek kesempatan kerja tidak langsungnya, terutama lewat keterkaitan produksi ke sektor-sektor hulu dan hilir: kesempatan kerja yang meningkat di usaha-usaha lain seperti transportasi, jasa, industri-industri yang membuat berbagai macam keperluan industri meubel, termasuk industri kayu, paku, cet, dan plitur, dan lewat keterkaitan konsumsi, yakni kesempatan kerja yang tumbuh di usaha-usaha seperti industri pakaian, rumah makan, transportasi, dan lainnya akibat permintaan konsumsi meningkat dari pekerjapekerja (dan keluarga-keluarga mereka) di UMK meubel. Jadi, dengan asumsi faktor-faktor berpengaruh lainnya tidak berubah, dapat dibayangkan berapa besar efek positif dari keberadaan UMK meubel di Jepara terhadap pengurangan kemiskinan di wilayah tersebut.

Dua ciri penting lainnya dari UMK Indonesia yang berorientasi ekspor adalah: (1) banyak dari mereka yang tidak menjual semua

Tabel 7. Jumlah UMK di Industri Manufaktur menurut Provinsi dan Tujuan Pasar Tahun 2010

\begin{tabular}{|c|c|c|c|c|}
\hline \multirow[t]{2}{*}{ Provinsi* } & \multirow[t]{2}{*}{ Unit } & \multicolumn{3}{|c|}{ Tujuan pasar } \\
\hline & & $\begin{array}{c}\text { Hanya dalam } \\
\text { negeri (DN) }\end{array}$ & $\begin{array}{l}\text { Hanya luar } \\
\text { negeri (LN) }\end{array}$ & $\begin{array}{c}\text { DN dan } \\
\text { LN }\end{array}$ \\
\hline 1 & 56118 & 55814 & - & 304 \\
\hline 2 & 66722 & 66196 & 254 & 272 \\
\hline 3 & 53050 & 52762 & 55 & 233 \\
\hline 4 & 12227 & 12199 & 7 & 21 \\
\hline 5 & 18900 & 18896 & 4 & - \\
\hline 6 & 51531 & 51531 & - & - \\
\hline 7 & 9091 & 9064 & - & 27 \\
\hline 8 & 81637 & 81593 & 14 & 30 \\
\hline 9 & 5666 & 5666 & - & - \\
\hline 10 & 11970 & 11876 & 70 & 24 \\
\hline 11 & 28570 & 28445 & - & 125 \\
\hline 12 & 397331 & 396635 & 453 & 243 \\
\hline 13 & 659126 & 656785 & 2069 & 272 \\
\hline 14 & 63526 & 62724 & 526 & 276 \\
\hline 15 & 518327 & 517293 & 251 & 783 \\
\hline 16 & 65582 & 65563 & - & 19 \\
\hline 17 & 84701 & 79022 & 4626 & 1053 \\
\hline 18 & 83214 & 83186 & - & 28 \\
\hline 19 & 80465 & 80465 & - & - \\
\hline 20 & 29532 & 28976 & 198 & 358 \\
\hline 21 & 14145 & 14145 & - & - \\
\hline 22 & 55416 & 55405 & - & 11 \\
\hline 23 & 12017 & 11997 & - & 20 \\
\hline 24 & 28494 & 28493 & - & 1 \\
\hline 25 & 26767 & 26767 & - & - \\
\hline 26 & 84155 & 84093 & - & 62 \\
\hline 27 & 53373 & 53373 & - & - \\
\hline 28 & 18605 & 18582 & 23 & - \\
\hline 29 & 20551 & 20549 & - & 2 \\
\hline 30 & 26344 & 26342 & - & 2 \\
\hline 31 & 5834 & 5783 & - & 51 \\
\hline 32 & 1900 & 1900 & - & - \\
\hline 33 & 7837 & 7819 & - & 18 \\
\hline
\end{tabular}


produknya ke pasar ekspor tetapi sebagian untuk pasar domestik. Jadi mereka sebenarnya bukan eksportir sepenuhnya; dan (2) sebagian besar dari UMK yang ekspor melakukannya secara tidak langsung, melainkan lewat perantara seperti pedagang, pengumpul, perusahaan-perusahaan eksportir (biasanya dari kategori UB), atau lewat keterkaitan produksi dengan sistem subcontracting dengan UMB berorientasi ekspor, yang mana UMK biasanya membuat barang-barang setengah jadi dan selanjutnya proses akhir produksi dilakukan di UMB. Berkaitan dengan ciri pertama tersebut, seperti yang dapat dilihat di Tabel 7, data BPS 2010 menunjukkan bahwa hanya ada beberapa provinsi di Indonesia yang memiliki UMK berorientasi ekspor sepenuhnya), walaupun dalam persentase dari jumlah UMK yang ada, proporsinya relatif kecil. Lebih jelas lagi dapat dilihat di Gambar 12 bahwa provinsi Bali (No. 17) memiliki proporsi terbesar dari jumlah UMK yang ada di pulau tersebut yang melakukan ekspor 100 persen. Paling tidak ada satu alasan kunci, yakni sebagai lokasi turis terbesar atau terpopuler di Indonesia, Bali memiliki jaringan-jaringan kerja terluas dengan pasar-pasar internasional untuk ekspor UMK (mungkin pada peringkat kedua dipegang oleh Jepara). Tetapi posisi Bali itu bisa juga disebabkan oleh banyak jumlah UMK di Bali yang melakukan ekspor tetapi sebenarnya bukan dalam bentuk menjual barang-barang mereka secara langsung ke luar negeri tetapi menjualnya ke wisatawan-wisatawan asing yang berkunjung ke pulau tersebut. Sesuai klasifikasi internasional mengenai perdagangan antar negara, menjual ke warga negara asing yang berkunjung ke dalam negeri namun tidak memiliki ijin tinggal juga dianggap kegiatan ekspor.

Mengenai ciri kedua tersebut, sebuah laporan dari Bank Pembangunan Asia (ADB, 2002) mengenai UMK dan UM (sebut saja UMKM) di Indonesia juga mengungkapkan bahwa rendahnya representasi dari UMKM Indonesia dalam ekspor dibandingkan dengan UB sebagian disebabkan oleh banyaknya UMKM yang melakukan ekspor lewat perantara baik di tingkat nasional maupun internasional. Akibatnya, mereka tidak tercatat secara resmi sebagai eksportir. Pihak perantara biasanya mengumpulkan produk-produk dari UMKM atau seperti dalam kasus subcontracting pihak perantara memberikan pesanan kepada UMKM, bisa dalam bentuk barang jadi atau setengah jadi. Jadi sangat jelas bahwa dalam sistem perdagangan internasional seperti ini, pihak perantara memainkan sebuah peran yang sangat penting atau bahkan sangat dominan dalam membuat keputusan dalam banyak aspek, termasuk menentukan jumlah dan disain barang, warna, harga, teknologi yang digunakan, dan waktu penyerahan barang. Jadi, nyaris UMKM bersangkutan tidak punya pengaruh atau tidak terlibat sama sekali dalam keputusankeputusan atau penentuan-penentuan di luar proses produksi itu sendiri. Bahkan sering kali orang mengatakan bahwa dalam praktek dagang seperti ini, yang mana pihak pembeli (dalam hal ini, pihak perantara) adalah motor utama pertumbuhan ekspor UMKM, UMKM yang terlibat sebenarnya tidak beda dengan buruh/tenaga kerja yang digaji yang bekerja di rumah-rumah.

Walaupun sering kali peran perantara sedemikian dominannya sehingga UMKM yang terlibat lebih dirugikan daripada diuntungkan, namun ada hal-hal yang menguntungkan UMKM, khususnya mereka yang tidak memiliki kemampuan melakukan pemasaran internasional secara mandiri. Keuntungan dari sisi para output (permintaan) adalah menghubungkan UMKM dengan jaringan-jaringan pasar internasional (calon-calon pembeli di luar negeri); jadi ada semacam jaminan pasar bagi UMKM dengan biaya pemasaran yang rendah atau bahkan nihil. Dari sisi pasar input (penawaran/ produksi), pihak perantara sering kali menyediakan input-input penting seperti modal, teknologi, pendampingan dan bahkan saran-saran untuk meningkatkan kualitas barang dan bagaimana mendapatkan hak paten terhadap produk yang dibuatnya.

Sayangnya, data yang ada mengenai UMK per provinsi seperti data BPS 2010 tersebut tidak memberikan informasi mengenai peran perantara dalam kegiatan ekspor UMK. Padahal pola dagang seperti ini sangat membantu dalam menilai sejauh mana UMK yang terlibat dalam kegiatan ekspor bermanfaat bagi kesejahteraan warga atau berdampak positif pada pengurangan kemiskinan di daerah. Teori dasarnya atau hipotesisnya adalah bahwa semakin dominan peran perantara semakin kecil efek positif dari keterlibatan UMK dalam ekspor terhadap kesejahteraan warga, khususnya pekerja dan pemilik UMK bersangkutan karena fakta menunjukkan bahwa pihak produsen sering kali mendapatkan harga jual yang tidak menguntungkan. Pihak perantara tidak selalu harus dari provinsi yang sama atau bahkan bisa dari luar negeri, sehingga dapat diasumsikan bahwa semakin besar kekuasaan pihak perantara dari luar provinsi dalam kemitraan dagang dengan UMK lokal semakin kecil dampaknya terhadap kesejahteraan masyarakat lokal.

\section{Kendala-Kendala Utama}

Perkembangan UMK di Indonesia sering terhalang oleh banyak hambatan. Hambatan-hambatan tersebut (atau intensitasnya) bisa berbeda antara satu daerah dan daerah lain, atau antara perdesaan dan perkotaan, atau antar sektor, atau antar perusahaan di sektor yang sama. Namun demikian, ada sejumlah persoalan yang umum untuk semua UMK di negara manapun juga, khususnya di negara-negara berkembang, termasuk Indonesia, yakni keterbatasan modal kerja maupun modal investasi, kesulitankesulitan dalam pemasaran, distribusi dan pengadaan bahan baku dan input-input lainnya, keterbatasan 
Tabel 8. Jumlah UMK di Industri Manufaktur Menurut Kendala Utama dan Provinsi Tahun 2010

\begin{tabular}{|c|c|c|c|c|c|c|c|c|c|}
\hline \multirow[t]{2}{*}{ Provinsi } & \multirow[t]{2}{*}{ Jumlah } & \multirow{2}{*}{$\begin{array}{c}\text { yang } \\
\text { Berkendala } \\
\text { Serius }\end{array}$} & \multicolumn{7}{|c|}{ Jenis Kendala Utama * } \\
\hline & & & 1 & 2 & 3 & 4 & 5 & 6 & 7 \\
\hline Aceh & 56118 & 41797 & 9533 & 9752 & 19611 & 285 & 556 & 1093 & 967 \\
\hline Sumut & 66722 & 57636 & 12018 & 15613 & 22006 & 1381 & 519 & 2054 & 4045 \\
\hline Sumbar & 53050 & 37613 & 6742 & 7746 & 18086 & 205 & 119 & 1970 & 2745 \\
\hline Riau & 12227 & 10389 & 1586 & 3707 & 3880 & 229 & 95 & 255 & 637 \\
\hline Jambi & 18900 & 15292 & 2979 & 4046 & 6785 & 363 & 48 & 635 & 436 \\
\hline Sumsel & 51531 & 44854 & 11965 & 5743 & 19992 & 270 & 788 & 813 & 5283 \\
\hline Bengkulu & 9091 & 8299 & 1824 & 2146 & 3674 & 31 & 204 & 118 & 302 \\
\hline Lampung & 81637 & 69812 & 17996 & 14626 & 25929 & 2793 & 1372 & 2072 & 4430 \\
\hline Bangka & 5666 & 4794 & 1149 & 1327 & 1803 & 74 & 56 & 87 & 296 \\
\hline Belitung & 11970 & 10217 & 2874 & 2523 & 3356 & 36 & 752 & 316 & 360 \\
\hline Kep. Riau & 28570 & 23099 & 3573 & 7725 & 8224 & 207 & 285 & 1352 & 1733 \\
\hline DKI Jakarta & 397331 & 335383 & 82905 & 74952 & 115943 & 9454 & 4970 & 15808 & 31351 \\
\hline Jabar & 659126 & 478040 & 131755 & 102725 & 160944 & 3677 & 5800 & 22806 & 50333 \\
\hline Jateng & 63526 & 44835 & 6065 & 12687 & 15295 & 239 & 89 & 2853 & 7607 \\
\hline DIY & 518327 & 367728 & 77222 & 108118 & 125459 & 4760 & 5136 & 13620 & 33413 \\
\hline Jatim & 65582 & 55723 & 8897 & 7056 & 27650 & 538 & 1735 & 2134 & 7713 \\
\hline Banten & 84701 & 67862 & 15292 & 14388 & 26678 & 498 & 1679 & 1826 & 7501 \\
\hline Bali & 83214 & 67395 & 5794 & 16917 & 35011 & 364 & 4516 & 3434 & 1359 \\
\hline NTB & 80465 & 77177 & 9698 & 20814 & 36903 & 2552 & 496 & 5903 & 811 \\
\hline NTT & 29532 & 22691 & 5412 & 4569 & 7789 & 696 & 1925 & 715 & 1585 \\
\hline Kalbar & 14145 & 11587 & 3186 & 3750 & 3771 & 151 & 139 & 153 & 437 \\
\hline Kalteng & 55416 & 46029 & 13143 & 10678 & 15242 & 146 & 99 & 4163 & 2558 \\
\hline Kalsel & 12017 & 10453 & 2428 & 2203 & 4226 & 297 & 245 & 252 & 802 \\
\hline Kaltim & 28494 & 21076 & 6957 & 3233 & 7735 & 1125 & 688 & 946 & 392 \\
\hline Sulut & 26767 & 22733 & 5182 & 3156 & 11520 & 269 & 179 & 631 & 1796 \\
\hline Sulteng & 84155 & 68380 & 15272 & 14683 & 29724 & 2821 & 665 & 1340 & 3875 \\
\hline Sulsel & 53373 & 47017 & 8784 & 7679 & 20128 & 1803 & 374 & 382 & 7867 \\
\hline Sultengg & 18605 & 15352 & 2595 & 1784 & 8206 & 1090 & 605 & 358 & 714 \\
\hline Gorontalo & 20551 & 16034 & 3312 & 2532 & 7673 & 730 & 302 & 523 & 962 \\
\hline Sulbar & 26344 & 22033 & 5051 & 5180 & 8107 & 2034 & 71 & 123 & 1467 \\
\hline Maluku & 5834 & 4751 & 774 & 1024 & 2227 & 225 & 142 & 76 & 283 \\
\hline Maluku Utara & 1900 & 1612 & 372 & 429 & 678 & - & 25 & 33 & 75 \\
\hline $\begin{array}{l}\text { Papua Barat } \\
\text { Papua }\end{array}$ & 7837 & 6034 & 1133 & 1612 & 2503 & 228 & 83 & 202 & 273 \\
\hline
\end{tabular}

Catatan: * (1) kekurangan bahan baku atau harganya mahal, (2) kesulitan-kesulitan dalam pemasaran, (3) keterbatasan modal, (4) hambatan-hambatan transportasi/distribusi, (5) kekurangan energi atau harganya mahal, (6) kekurangan pekerja terampil atau biaya tenaga kerja mahal, dan (7) kendala-kendala utama lainnya.

Sumber: BPS (2010a).

akses ke informasi mengenai peluang pasar dan lainnya, keterbatasan pekerja dengan keahlian tinggi (kualitas SDM rendah), rendahnya kemampuan teknologi, biaya transportasi dan energi yang tinggi, keterbatasan komunikasi, biaya transaksi yang tinggi akibat prosedur administrasi dan birokrasi yang kompleks khususnya dalam pengurusan izin usaha, dan ketidakpastian akibat peraturan dan kebijaksanaan ekonomi yang tidak jelas atau tidak menentu arahnya (Urata, 2000; Tambunan, 2009a,b,c).

Berdasarkan data BPS 2010, Tabel 8 menunjukkan bahwa proporsi dari UMK di industri manufaktur yang menghadapi problem-problem serius dalam jumlah maupun jenis masalah berbeda antar provinsi. Perbedaan ini bisa terkait dengan perbedaan-perbedaan dalam berbagai macam karakteristik lokal dari masing-masing provinsi seperti ketersediaan infrastruktur (dalam jumlah maupun kualitas) seperti pelabuhan laut atau udara, jalan raya, lokasi industri beserta komponen- komponen pendukungnya, fasilitas penerangan dan telekomunikasi, serta fasilitas transportasi; lokasi geografi, terutama jaraknya dengan kota-kota penting atau pusat-pusat kegiatan ekonomi dan administrasi pemerintah seperti Jakarta, Surabaya dan Makassar); kebijakan-kebijakan pemerintah daerah (Pemda); dan kondisi pasar lokal (yang sangat ditentukan oleh jumlah penduduk, pendapatan ratarata penduduk, lokasi atau akses masyarakat ke pasar, dan persaingan baik antar sesame UMK maupun antara UMK dengan UMB dan barangbarang impor).

UMK yang mengalami kesulitan modal adalah terutama mereka yang berlokasi di perdesaan atau di wilayah-wilayah terbelakang atau relatif terisolasi di mana biasanya tidak terdapat kantor bank atau lembaga keuangan non-bank sehingga mereka tidak mendapatkan akses ke skim-skim kredit yang ada dari pemerintah yang khusus diperuntukkan bagi UMK (seperti misalnya kredit 
Tabel 9. Jumlah UMK di Industri Manufaktur Menurut Sumber Pendanaan dan Provinsi Tahun 2010

\begin{tabular}{|c|c|c|c|c|}
\hline \multirow[t]{2}{*}{ Provinsi } & \multirow{2}{*}{ Jumlah } & \multicolumn{3}{|c|}{ Sumber Pendanaan } \\
\hline & & $\begin{array}{c}\text { Sepenuhnya } \\
\text { uang } \\
\text { sendiri }\end{array}$ & $\begin{array}{l}\text { Sebagian } \\
\text { eksternal }\end{array}$ & $\begin{array}{c}\text { Sepenuhnya } \\
\text { eksternal }\end{array}$ \\
\hline Aceh & 56118 & 49610 & 6092 & 416 \\
\hline Sumut & 66722 & 54230 & 8528 & 3964 \\
\hline Sumbar & 53050 & 39305 & 10299 & 3446 \\
\hline Riau & 12227 & 10914 & 1166 & 147 \\
\hline Jambi & 18900 & 15454 & 3069 & 377 \\
\hline Sumsel & 51531 & 38460 & 10118 & 2953 \\
\hline Bengkulu & 9091 & 7284 & 1438 & 369 \\
\hline Lampung & 81637 & 64684 & 12380 & 4573 \\
\hline Bangka & 5666 & 4913 & 530 & 223 \\
\hline Belitung & 11970 & 11414 & 464 & 92 \\
\hline Kep. Riau & 28570 & 21990 & 5132 & 1448 \\
\hline DKI Jakarta & 397331 & 287277 & 96762 & 13292 \\
\hline Jabar & 659126 & 534073 & 113585 & 11468 \\
\hline Jateng & 63526 & 46336 & 13464 & 3726 \\
\hline DIY & 518327 & 418145 & 83644 & 16538 \\
\hline Jatim & 65582 & 54022 & 9589 & 1971 \\
\hline Banten & 84701 & 58557 & 15943 & 10201 \\
\hline Bali & 83214 & 60006 & 20370 & 2838 \\
\hline NTB & 80465 & 73017 & 6744 & 704 \\
\hline NTT & 29532 & 26575 & 2679 & 278 \\
\hline Kalbar & 14145 & 11329 & 2372 & 444 \\
\hline Kalteng & 55416 & 41558 & 876 & 5090 \\
\hline Kalsel & 12017 & 9996 & 1666 & 355 \\
\hline Kaltim & 28494 & 26852 & 1583 & 59 \\
\hline Sulut & 26767 & 22430 & 3172 & 1165 \\
\hline Sulteng & 84155 & 68867 & 8413 & 6875 \\
\hline Sulsel & 53373 & 46140 & 6209 & 1024 \\
\hline Sultengg & 18605 & 13907 & 3116 & 1582 \\
\hline Gorontalo & 20551 & 16632 & 3494 & 425 \\
\hline Sulbar & 26344 & 25032 & 1167 & 145 \\
\hline Maluku & 5834 & 5375 & 429 & 30 \\
\hline Maluku Utara & 1900 & 1674 & 183 & 43 \\
\hline $\begin{array}{l}\text { Papua Barat } \\
\text { Papua }\end{array}$ & 7837 & 6695 & 845 & 297 \\
\hline
\end{tabular}

usaha rakyat atau KUR). Konsekwensinya, mereka menjadi sangat tergantung sepenuhnya pada uang mereka sendiri, atau sebagian atau sepenuhnya pada pinjaman dari kerabat atau keluarga atau dari peminjam-peminjam informal yang sering kali menawarkan pinjaman dalam jumlah yang dibutuhkan yang bisa dicairkan dalam waktu singkat tanpa proses administrasi yang ruwet dan tanpa keharusan menyediakan jaminan, namun dengan bunga pinjaman yang lebih mahal daripada yang resmi berlaku di pasar. Tiga rasio tersebut menurut provinsi dapat dilihat di Tabel 9.

Selanjutnya, data BPS pada tingkat nasional menunjukkan bahwa UMK di semua sektor yang mendanai usahanya dari sumber-sumber eksternal, meminjam tidak hanya dari bank atau lembagalembaga non-bank tetapi juga dari sumber-sumber informal seperti pinjaman dari kerabat, keluarga maupun tukang kredit informal. Dalam kata lain, banyak dari UMK di Indonesia yang mendapat dana dari berbagai sumber, baik formal maupun informal. Sedangkan pada tingkat provinsi, berdasarkan data
BPS 2010 mengenai UMK di industri manufaktur, Tabel 10 memperlihatkan bahwa derajat dari diversifikasi sumber-sumber pendanaan eksternal tidak sama antar provinsi. Ada sejumlah provinsi dimana peran dari sumber-sumber pendanaan informal sangat penting bagi kelangsungan hidup kegiatan-kegiatan UMK. Alasan adanya perbedaan dalam diversifikasi sumber pendanaan eksternal antar provinsi tersebut (atau alasan kenapa banyak UMK yang sangat mengandalkan uang sendiri atau tidak tergantung sepenuhnya pada sumber-sumber eksternal formal) sebagian adalah karena biasanya pinjaman yang di dapat dari perbankan atau lembaga-lembaga keuangan formal non-bank tidak selalu mencukupi kebutuhan sehingga mereka harus juga menggunakan sumber-sumber informal. Misalnya, banyak kalangan beranggapan bahwa plafon dari Kredit Usaha Rakyat (KUR) yakni maksimum Rp 20 juta sangat tidak cukup, apalagi untuk memperluas usaha atau untuk menggantikan alat-alat produksi. Selain itu, banyak juga pengusaha UMK yang menganggap bahwa bunga pinjaman dari 
Tabel 10. Jumlah UMK di Industri Manufaktur Menurut Sumber Eksternal dan Provinsi Tahun 2010

\begin{tabular}{|c|c|c|c|c|c|c|c|c|c|}
\hline \multirow[t]{2}{*}{ Provinsi } & \multirow[t]{2}{*}{ Jumlah } & \multirow{2}{*}{$\begin{array}{l}\text { Memakai } \\
\text { sumber } \\
\text { eksternal }\end{array}$} & \multicolumn{7}{|c|}{ Sumber eksternal* } \\
\hline & & & 1 & 2 & 3 & 4 & 5 & 6 & 7 \\
\hline Aceh & 56118 & 6508 & 664 & 988 & 416 & - & 2634 & 1681 & 125 \\
\hline Sumut & 66722 & 12492 & 3137 & 756 & 167 & 21 & 3423 & 1054 & 3837 \\
\hline Sumbar & 53050 & 13745 & 3335 & 617 & 998 & 208 & 3387 & 785 & 4415 \\
\hline Riau & 12227 & 1313 & 372 & 138 & 98 & - & 381 & 212 & 112 \\
\hline Jambi & 18900 & 3446 & 887 & 197 & 86 & - & 1447 & 482 & 347 \\
\hline Sumsel & 51531 & 13071 & 438 & 276 & 50 & - & 9047 & 1248 & 1729 \\
\hline Bengkulu & 9091 & 1807 & 726 & 154 & 45 & - & 512 & 238 & 131 \\
\hline Lampung & 81637 & 16953 & 2469 & 625 & 313 & - & 10152 & 2014 & 1336 \\
\hline Bangka Belitung & 5666 & 753 & 291 & 175 & 39 & 5 & 47 & 68 & 128 \\
\hline Kep. Riau & 11970 & 556 & 99 & - & 25 & - & 306 & 18 & 108 \\
\hline DKI Jakarta & 28570 & 6580 & 1137 & 326 & 92 & 52 & 2246 & 1862 & 836 \\
\hline Jabar & 397331 & 110054 & 17413 & 4331 & 1487 & 411 & 41835 & 9359 & 33466 \\
\hline Jateng & 659126 & 125053 & 27932 & 3842 & 5555 & 939 & 43469 & 9357 & 33849 \\
\hline DIY & 63526 & 17190 & 4064 & 1586 & 1110 & $\backslash 138$ & 4746 & 478 & 5063 \\
\hline Jatim & 518327 & 100182 & 22527 & 4820 & 4204 & - & 40085 & 9765 & 17378 \\
\hline Banten & 65582 & 11560 & 1258 & 809 & 206 & 18 & 6387 & 2014 & 868 \\
\hline Bali & 84701 & 26144 & 7684 & 2071 & 2024 & 46 & 7077 & 750 & 6371 \\
\hline NTB & 83214 & 23208 & 3571 & 1304 & 1084 & - & 9958 & 3011 & 4234 \\
\hline NTT & 80465 & 7448 & 1590 & 1862 & 1743 & - & 720 & 504 & 1029 \\
\hline Kalbar & 29532 & 2957 & 1357 & 228 & 210 & - & 394 & 375 & 379 \\
\hline Kalteng & 14145 & 2816 & 488 & 206 & 39 & - & 835 & 956 & 287 \\
\hline Kalsel & 55416 & 13858 & 1878 & 197 & 343 & 20 & 5117 & 4304 & 1999 \\
\hline Kaltim & 12017 & 2021 & 956 & 177 & 44 & 10 & 623 & 134 & 73 \\
\hline Sulut & 28494 & 1642 & 392 & 69 & 84 & 13 & 708 & 121 & 255 \\
\hline Sulteng & 26767 & 4337 & 934 & 183 & 1092 & 48 & 1231 & 492 & 357 \\
\hline Sulsel & 84155 & 15288 & 3669 & 958 & 522 & 12 & 4366 & 1501 & 4251 \\
\hline Sultengg & 53373 & 7233 & 1029 & 673 & 263 & - & 1939 & 701 & 2616 \\
\hline Gorontalo & 18605 & 4698 & 690 & 253 & 71 & 45 & 2156 & 842 & 641 \\
\hline Sulbar & 20551 & 3919 & 698 & 186 & 1511 & - & 364 & 1043 & 117 \\
\hline Maluku & 26344 & 1312 & 115 & 609 & 120 & - & 175 & 285 & 8 \\
\hline Maluku Utara & 5834 & 459 & 52 & 42 & 17 & - & 164 & 175 & 9 \\
\hline Papua Barat & 1900 & 226 & 65 & 50 & - & _ & 76 & 20 & 15 \\
\hline Papua & 7837 & 1142 & 710 & 19 & 69 & _- & 208 & 90 & 46 \\
\hline
\end{tabular}

individu/perorangan, (6) keluarga, (7) lainnya

Sumber: BPS (2010a).

perbankan relatif mahal selain urusan administrasinya sangat ruwet dengan berbagai persyaratan yang sering kali sulit untuk dipenuhi (Kusmulyono, 2008; Situmorang, dkk. 2008).

Dalam hal pendidikan formal dari pemilik usaha, pada tingkat nasional data BPS menunjukkan bahwa pemilik dari sebagian besar dari jumlah UMK yang beroperasi di semua sektor ekonomi hanya berpendidikan dasar (bahkan banyak dari mereka yang tidak sampai menamatkan sekolah dasar); walaupun tingkatnya bervariasi antar kelompok UMI dengan kelompok UK, dan juga bervariasi lintas sektor. Gambaran ini sesuai dengan fakta mengenai kondisi pendidikan formal dari masyarakat Indonesia berdasarkan hasil Survei Tenaga Kerja Nasional (BPS) yang menunjukkan bahwa sebagian besar dari angkatan atau tenaga kerja Indonesia hingga saat ini masih relatif rendah, walaupun ada peningkatan setiap 10 tahun: masih banyak orang di dalam kelompok umur antara 15 hingga 65 tahun yang hanya punya ijasa sekolah dasar (SD), atau hanya hingga sekolah menengah pertama (SMP) atau sekolah menengah atas (SMA); walaupun jumlah penduduk dengan gelar sarjana atau S3 setiap tahun meningkat. Tabel 11 menunjukkan tingkat pendidikan formal dari pemilik UMK di industri manufaktur yang derajatnya bervariasi antar provinsi. Perbedaan tersebut disebabkan oleh perbedaan-perbedaan dalam faktor-faktor utama penentu peningkatan pendidikan masyarakat di suatu wilayah, yakni, dari sisi pelajar: kemampuan finansial keluarga/orang tua, kesadaran orang tua akan pentingnya pendidikan lanjut, kesehatan dan kemauan individu pelajar, dan, dari sisi pemberi pendidikan antara lain: kuantitas dan kualitas bangunan sekolah dan pengajar, sistem pendidikan yang diterapkan, jalur-jalur pendidikan yang tersedia, dan biaya pendidikan resmi dan tidak resmi. Selain itu, infrastruktur baik dalam kuantitas dan kualitas, sebaran pemukiman dan sekolah, serta kebijakan pemerintah daerah yang secara langsung maupun 
Tabel 11. Jumlah UMK di Industri Manufaktur Menurut Tingkat Pendidikan Formal Pemilik UMK dan Provinsi Tahun 2010

\begin{tabular}{|c|c|c|c|c|c|c|c|}
\hline \multirow[t]{2}{*}{ Provinsi } & \multirow[t]{2}{*}{ Jumlah } & \multicolumn{6}{|c|}{ Tingkat pendidikan formal* } \\
\hline & & $\mathbf{1}$ & 2 & 3 & 4 & 5 & 6 \\
\hline Aceh & 56118 & 10047 & 15371 & 15960 & 13665 & 636 & 439 \\
\hline Sumut & 66722 & 12458 & 21869 & 14228 & 17116 & 117 & 934 \\
\hline Sumbar & 53050 & 9006 & 12224 & 13390 & 16591 & 386 & 1453 \\
\hline Riau & 12227 & 2624 & 4196 & 2554 & 2431 & 325 & 97 \\
\hline Jambi & 18900 & 4092 & 6102 & 3106 & 5165 & 149 & 286 \\
\hline Sumsel & 51531 & 9853 & 22968 & 9757 & 8179 & 197 & 577 \\
\hline Bengkulu & 9091 & 1330 & 2440 & 2132 & 2823 & 197 & 169 \\
\hline Lampung & 81637 & 18548 & 33877 & 16622 & 11949 & 255 & 386 \\
\hline Bangka Belitung & 5666 & 1452 & 2114 & 758 & 1117 & 49 & 176 \\
\hline Kep. Riau & 11970 & 3757 & 4470 & 2063 & 1549 & 99 & 32 \\
\hline DKI Jakarta & 28570 & 2542 & 6925 & 7677 & 9604 & 646 & 1176 \\
\hline Jabar & 397331 & 63630 & 229001 & 61972 & 38161 & 1620 & 2947 \\
\hline Jateng & 659126 & 196949 & 312184 & 86586 & 52395 & 4087 & 6925 \\
\hline DIY & 63526 & 14254 & 18678 & 12626 & 15686 & 1068 & 1214 \\
\hline Jatim & 518327 & 131944 & 229809 & 92266 & 57246 & 1178 & 5884 \\
\hline Banten & 65582 & 27469 & 26230 & 6475 & 4826 & 131 & 451 \\
\hline Bali & 84701 & 20433 & 27716 & 16191 & 17528 & 1382 & 1451 \\
\hline NTB & 83214 & 33374 & 26765 & 11926 & 9108 & 531 & 1510 \\
\hline NTT & 80465 & 30384 & 35834 & 6676 & 6991 & 124 & 456 \\
\hline Kalbar & 29532 & 7822 & 8360 & 6029 & 6677 & 194 & 450 \\
\hline Kalteng & 14145 & 2198 & 5530 & 3646 & 2563 & 107 & 101 \\
\hline Kalsel & 55416 & 15598 & 26888 & 6405 & 5430 & 634 & 461 \\
\hline Kaltim & 12017 & 2552 & 4260 & 2890 & 2083 & 120 & 112 \\
\hline Sulut & 28494 & 2816 & 12564 & 7530 & 5349 & 174 & 61 \\
\hline Sulteng & 26767 & 5108 & 10858 & 5572 & 4926 & 102 & 201 \\
\hline Sulsel & 84155 & 28086 & 30170 & 11601 & 13151 & 424 & 723 \\
\hline Sultengg & 53373 & 16997 & 17018 & 11433 & 6925 & 553 & 447 \\
\hline Gorontalo & 18605 & 6886 & 7671 & 2136 & 1774 & 74 & 64 \\
\hline Sulbar & 20551 & 5238 & 9194 & 2611 & 3096 & 123 & 289 \\
\hline Maluku & 26344 & 3615 & 11433 & 5198 & 5466 & 205 & 427 \\
\hline Maluku Utara & 5834 & 793 & 2269 & 1207 & 1471 & 32 & 62 \\
\hline Papua Barat & 1900 & 288 & 604 & 342 & 648 & 1 & 17 \\
\hline Papua & 7837 & 1329 & 2545 & 1620 & 2095 & 56 & 192 \\
\hline
\end{tabular}

Catatan: * (1) tidak tamat SD, (2) hanya tamat SD, (3) hanya tamat SMP, (4) hanya tamat SMA, (5) punya ijasa D I/II/III, (6) punya diploma sarjana.

Sumber: BPS (2010).

tidak langsung mempengaruhi proses pendidikan di suatu wilayah juga sangat berperan.

Tidak diragukan bahwa perbedaanperbedaan dalam tingkat pendidikan formal pemilik UMK dan akses ke sumber-sumber formal pendaaan antar provinsi turut menjelaskan adanya perbedaan dalam kinerja UMK menurut provinsi seperti yang telah diperlihatkan dan dibahas sebelumnya di atas. Pendidikan formal dan mudahnya akses ke pendanaan formal adalah dua faktor utama penentu produktivitas dan kualitas produk yang selanjutnya menentukan tingkat daya saing UMK. Apalagi sekarang ini dalam era globalisasi dan liberalisasi perdagangan dunia, semua provinsi di Indonesia menjadi sangat rentan terhadap semakin sengitnya persaingan dari luar lewat masuknya barang-barang dan jasa-jasa yang lebih murah atau yang kualitasnya lebih banyak. Jangankan industri, rumah makanrumah makan lokalpun bisa tergusur oleh rumah makan-rumah cepat saji yang berasal dari luar. Hal ini jelas bisa mengancam kelangsungan hidup UMK di provinsi-provinsi. Tidak mungkin UMK bisa meningkatkan produktivitasnya dan melakukan inovasi untuk meningkatkan kualitas produknya tanpa memiliki pendidikan formal yang tinggi dan dana yang cukup. Inovasi sangat membutuhkan keahlian formal dan dana yang banyak, dan inovasi sekarang ini menjadi senjata utama untuk bisa terus memperbaiki/meningkatkan daya saing agar bisa bertahan di dalam persaingan global yang semakin ketat.

\section{SIMPULAN DAN REKOMENDASI KEBIJAKAN}

Walaupun hanya memakai data UMK di industri manufaktur saja (idealnya harus memakai data UMK di semua sektor), studi ini bisa menyimpulkan bahwa UMK memiliki peran penting sebagai salah satu cara untuk memerangi kemiskinan di daerah (provinsi). Namun demikian, fakta yang muncul dari analisa ini adalah bahwa kinerja UMK 
yang berarti juga peran aktual dari kelompok usaha tersebut berbeda antar provinsi, yang tentu disebabkan oleh perbedaan-perbedaan dalam faktorfaktor lokal dan kendala-kendala yang dihadapi UMK seperti yang telah dijelaskan di dalam penelitian ini.

Walaupun sudah cukup banyak program pemerintah sejak era Orde Baru hingga sekarang untuk mendukung perkembangan UMK di tanah air, kinerja UMK dan kondisinya di Indonesia pada umumnya dan dibanyak provinsi pada khususnya masih jauh dari yang diharapkan. Jika kondisi seperti ini terus berlangsung, seperti yang telah disinggung sebelumnya di Bagian 5, tidak mustahil UMK di banyak provinsi akan lenyap karena masuknya barang-barang dan jasa-jasa dari luar negeri, khususnya dari China, dengan keunggulankeunggulannya.

Oleh sebab itu, banyak hal yang perlu dilakukan oleh pemerintah, khususnya pemerintah daerah, yang diantaranya adalah:

1. Pembangunan infrastruktur baik fisik (seperti jalan raya, listrik dan fasilitas komunikasi, dan pelabuhan) dan non-fisik (seperti bank/lembaga pendanaan, pusat informasi, lembaga pendidikan/pelatihan, litbang/lab), mulai di tingkat desa, kecamatan, kabupaten hingga di tingkat provinsi.

2. Pemberdayaan kembali semua sentra-sentra UMK yang sempat dikembangkan dengan dukungan pemerintah pada era Orde Baru, namun terlantarkan sejak mulainya era reformasi. Khususnya Unit Pelayanan Teknis (UPT) di sentra-sentra yang ada perlu diremajakan dengan antara lain menggantikan mesin-mesin dan alat-alat pengujian/lab yang sudah usang dengan yang baru.

3. Walaupun bantuan pendanaan memang penting, namun sudah saatnya penekanan dari kebijakan atau program-program pemerintah untuk membantu perkembangan UMK lebih pada peningkatan pendidikan pengusaha dan pekerja, pengembangan teknologi, dan peningkatan kemampuan inovasi. Selain itu, UMK baik yang hanya melayani pasar domestik maupun yang menjual produk-produknya ke pasar luar negeri perlu dibantu sepenuhnya (misalnya dengan penyediaan lab. untuk pengujian kualitas barag) agar bisa mendapatkan label Standarisasi Nasional Indonesia (SNI) untuk meningkatkan kualitas produk dan berarti juga daya saing UMK.Untuk maksud ini, perlu adanya intensif agar terjalin kerjasama yang erat antara UMK setempat dengan perguruan tinggi, lembaga pendidikan/pelatihan dan litbang setempat sehingga terjadi peralihan teknologi dan pengetahuan ke UMK.

4. Perlu diupayakan peningkatan keterkaitan produksi lewat misalnya subcontracting antara UMK dan UB (usaha besar), termasuk perusahaan-perusahaan asing (PMA) yang beroperasi di daerah. Berdasarkan fakta bahwa sulit mendapatkan UMK lokal yang siap sebagai pemasok bagi UB/PMA karena keterbatasan teknologi dan pengetahuan, maka untuk mencapai tujuan ini, pemerintah daerah bersama-sama dengan pihak swasta seperti Kamar Dagang dan Industri Daerah (Kadinda), asosiasi bisnis, himpunan pengusaha, dan universitas harus sepenuhnya membantu UMK dalam meningkatkan kemampuan mereka sebagai pemasok yang kompetitif dan efisien bagi UB/PMA.

5. Dalam mengembangkan enam koridor ekonomi dalam rangka MP3EI, pengembangan UMK lokal di enam wilayah tersebut untuk menjadi UMK berdaya saing tinggi, baik sebagai pelaku usaha yang mandiri maupun sebagai pemasok UB, harus menjadi salah satu komponen penting dari kebijakan pengembangan enam koridor tersebut.

6. Perlu diupayakan agar semua UMK di manapun lokasinya mendapatkan akses sepenuhnya ke informasi mengenai pasar dan lainnya, teknologi, pendidikan/pelatihan, fasilitas perdagangan, dan perbankan; tentu dengan tidak menghilangan penilaian obyektif mengenai kelayakan usaha dari UMK bersangkutan.

\section{DAFTAR PUSTAKA}

Asian Development Bank. 2002. "Report and Recommendation of the President to the Boards of Directors on a Proposed Loan and Technical Assistance Grant to the Republic of Indonesia for the Small and Medium Enterprise Export Development Project", ADB RRP: INO 34331, November, Jakarta: Asian Development Bank.

Asian Development Bank. 2009. Key Indicators for Asia and the Pacific 2009, Manila: Asian Development Bank.

Badan Pusat Statistik. 2010a. Profil Industri Mikro dan Kecil 2010 (profile of micro and small industries), Jakarta: Badan Pusat Statistik.

Badan Pusat Statistik. 2010b. Data dan Informasi Kemiskinan Kabupaten Kota 2010, Jakarta: Badan Pusat Statistik.

Goh, Mark 2007. "High-growth, Innovative Asian SMEs for International Trade and Competiitveness: Challenges and Solutions for APO Member Countries", Tokyo: Asian Productivity Organization.

Kusmulyono, B. S. 2008. "Upaya pemberdayaan usaha mikro dan kecil melalui lembaga keuangan mikro", makalah, lokakarya "transformasi peran koperasi dan UMKM dalam lima tahun mendatang", 28 Oktober, Bappenas, Jakarta.

Sandee, Henry dan J. ter Wingel. 2002. "SME Cluster Development Strategies in Indonesia: What Can We Learn from Successful Clusters?", makalah dipresentasikan dalam JICA Workshop on 
Strengthening Capacity of SME Clusters in Indonesia, 5-6 Maret, Jakarta.

Situmorang, Johnny W. dan Jannes Situmorang. 2008. "Suku Bunga Perbankan Masih Menghambat Pembiayaan UMKM di Indonesia", makalah, Jakarta:Kementerian Koperasi dan UMKM.

Tambunan, Tulus T. H. 2009a. SME in Asian Developing Countries. London: Palgrave Macmillan Publisher.

Tambunan, Tulus T. H. 2009b. Development of SMEs in ASEAN Countries. New Delhi: Readworthy Publications, Ltd, New Delhi

Tambunan, Tulus T. H. 2009c. UMKM di Indonesia. Jakarta: Ghalia Indonesia.

Tambunan, Tulus. 2010. Trade Liberalization and SMEs in ASEAN, New York: Nova Science Publishers, Inc.

Tambunan, Tulus. 2012. 'Export-Oriented MSMEs' Acess to Trade Facilitation: The Story from Indonesia", Agustus, laporan penelitian untuk UN-ESCAP, Bangkok.

UNESCAP. 2009. Globalization of Production and the Competitiveness of Small and Medium-sized Enterprises in Asia and the Pacific:Trends and Prospects, Studies in Trade and Investment 65, Bangkok: United Nations.

Urata, Shujiro. 2000. 'Policy Recommendations for SME Promotion in Indonesia', report to the Coordination Ministry of Economy, Finance and Industry, Jakarta. 